Bilir, Güzin (2020). "Anıtsal Yapılardaki Mezar Anlayışı: Heroondan Martyriuma”. Uludağ Üniversitesi Fen-Edebiyat Fakültesi Sosyal Bilimler Dergisi, C. 21, S. 39, s. 607-649.

DOI: 10.21550/sosbilder.672324

Araştırma Makalesi

\title{
ANITSAL YAPILARDAKİ MEZAR ANLAYIŞI: HEROONDAN MARTYRIUUMA
}

Güzin BİLIR*

Gönderim Tarihi: Ocak 2020

Kabul Tarihi: Şubat 2020

ÖZET

Anıtsal mezarlar, yapıldı̆̆ dönemlerin mimari disiplinlerini temel alırken, kişilerin ya da olayların unutulmamasını sağlamak amacıyla hafizalarda yer edecek boyutlarda ve formlarda yapılmışlardır. Bu mezar tipi, erken dönemlerde kentin kurucularına ya da kahramanlarına yapılırken, zamanla "kahramanlık" olgusundan çıkmış, maddi durum yeterliliğine göre sıradan vatandaşlar için de mezar yapısı olarak yapılmışlardır. 4. yüzyllda Hristiyanlı̆̆ın kabulüyle birlikte anıt mezar/heroon anlaylşı Klasik Dönem'deki gibi sadece savaş kahramanlarının, Roma Imparatorluk Dönemi'yle birlikte sadece zenginlerin veya asillerin değil, din şehitleri yani martyrlerin gömüldüğ̈̈ martyriumlar olarak karşımıza çıkmaktadır. Pagandaki kahraman kültü ve bu kültle birlikte oluşan heroonlar, erken 4. yüzyllla beraber martyr kültü ve martyrium yapılarının kökenini oluşturmuştur. Martyriumlar, tek tanrılı inanışa geçilen Geç Antik Çağ'da Hristiyanlık inancının kült yapılarından biri olarak zamanla kendi mimari tarzını ortaya koymuştur. Tüm bu farklılaşma sürecinin kahramanlık algısı üzerinde yarattı̆̆ değişimin yanı sıra genel mimari anlayıșta da kendini gösterdiğini söylemek mümkündür.

Anahtar Kelimeler: Martyrium, antt, mezar, kahraman, Hristiyanlık

Dr., Bursa Uludağ Üniversitesi Sosyal Bilimler Enstitüsü Arkeoloji Ana Bilim Dal1, gbilir81@gmail.com

Uludağ Üniversitesi Fen-Edebiyat Fakültesi Sosyal Bilimler Dergisi Uludağ University Faculty of Arts and Sciences Journal of Social Sciences

Cilt: 21 Sayı: 39 / Volume: 21 Issue: 39 


\title{
Grave Understanding of Monumental Buildings: From Heroon to Martyrium
}

\begin{abstract}
Monumental tombs are built in sizes and forms that will take place in the memories in order to ensure that people or events are not forgotten, while taking the architectural disciplines of their periods into account. While this grave type was made to the founders or heroes of the city in the early periods, it emerged from the phenomenon of "heroism" over time, and was constructed as a grave structure for ordinary citizens according to their financial situation adequacy. With the acceptance of Christianity in the 4th century, the monumental tomb / heroon concept emerges as martyrs where, as in the Classical Period, only the war heroes, the martyrs were buried, not only the rich or noble with the Roman Imperial Period. The hero cult in pagan and the heroons formed with this cult formed the origin of martyr cult and martyrium structures with the early 4th century. Martyriums, as one of the cult structures of the Christian faith in the Late Antiquity, in which monotheistic belief was passed, has developed its architectural style over time. It is possible to say that all this differentiation process has manifested itself in the general architectural understanding as well as the change on the perception of heroism.
\end{abstract}

Key words: Martyrium, monumental, tomb, hero, Christianity

\section{Giriş}

Yapılma amaçları ölen kişinin yaşarkenki konumunu ölümsüzleştirmek, gelecek nesillere aktarmak olan anıt mezarlar sıradan vatandaşlar için değil daha çok yöneticiler, kahramanlar, soylular için yapılmıştırlar (Özbek 2007: 167). Şehircilik anlayışının tam olarak oturduğu dönemlerden beri tıpkı büyük tapınaklar, tiyatrolar, kent meydanları, zafer anıtları gibi anıt mezarlarda siyasi ve sosyal propagandanın mimari yansıması olarak zenginlik ve refahın simgesi haline gelmiştir. Soylu yöneticiler ve kahramanlar için yapılan bu anıt mezarlar, onurlandırmanın ve ölümsüzleştirmenin birer simgesi olmuştur (Koch 2001: 82) (Resim 1-2). 
Anıtsal mezarların; tapınak planl ${ }^{1}$, ev tipi ${ }^{2}$, kule tipi ${ }^{3}$, tonozlu ${ }^{4}$ ve Helenistik Dönem'e özgü çokgen duvarlı ${ }^{5}$ gibi çeşitli plan özellikleriyle farklı tipleri bulunmaktadır. Bu mezar tipinin hepsinde, ölen kişiyi onurlandırmak ve ölümsüzleştirmek amacıyla yapıldıkları için anıt özelliği bulunmaktadır.

Anadolu'nun hemen hemen her bölgesinde karşılaştığımız bu anıt mezarlar birer heroon olarak kabul edilmelidir. MÖ 7. yüzyıldan itibaren heroonlar sadece kent kurucularına, kent halkı tarafindan onurlandırılan idarecilere, başarılı sporculara, bağış yapan hayırseverlere ve askeri anlamda başarılı olmuş "kahramanlara" ithafen yapılmıştır. Klasik Dönem'de de bu durum aynen devam etmiş ve kentin dışında belirli bir nokta da yer almışlardır. Helenistik Dönem ile birlikte geleneksel yaklaşım değişmiş, bu mezarlar kent içine

1 Tapınak planlı anıtsal mezarlar için Anadolu dışı örnek için bk. Sarsinya Müzesi'ndeki Asfionius Rufus Mezarı için bk. Toynbee 1971: 131; Karya bölgesinden Hekatomnidler zamanında Halikarnassos antik kentinde bulunan Maussoleion için bk. Başgelen 2007: 114-116; Mylassa antik kentinde bulunan Hekatamnos Anit Mezarı için bk. Arslan 2013: 51; Gümüşkesen Mezar Anıtı için bk. Bayburtluoğlu 1982: 131; Pisidia Bölgesi'ndeki Termessos kentinde bulunan Mamastis Mezarı için bk. Toynbee 1971: 131; Side'deki örnekler için bk. Mansel 1978: 296; Lykia bölgesindeki Ksanthos Nereidler ve Limyra mezar anıtları için bk. Borchardt 1999: 45-52; Troas bölgesindeki Parion antik kentindeki örnekler için bk. Kasapoğlu 2007: 486-487; Perge antik kentindeki örnekler için bk. Kara 2015: 434-438.

${ }^{2}$ Ev tipi anıtsal mezar örneklerinden Apia Yolu üzerindeki mezarlar ve Rabirius Mezarı için bk. https://rome.us/ancient-rome/the-appian-way.html; Anadolu'dan Lykia bölgesindeki örnekleri için bk. Özüdoğru 2008: 2.

${ }^{3}$ Bilindik en güzel örnekleri olan Suriye'deki Palmyra antik kentindeki örnekler için bk. Henning 2013; Anadolu'da Dağlık Kilikya bölgesindeki örnekler için bk. Akçay ve Erdem 2016; Olba kentindeki örnekler için bk. Machatschek 1974: 251-255 ve 258, res.: 56; Uzunburç'taki örnekler için bk. Erdem 2015: 123.

4 Kilikya bölgesinden Olba kentindeki örnekler için bk. Akçay 2008; Karya bölgesinden Iasos kentindeki örnekler için bk. Kızıl 1999: 54.

${ }^{5}$ Dağlık Kilikya bölgesindeki örnekler için bk. Söğüt 2006: 24. 
yaklaşmaya başlamış, MÖ 1. yüzyıldan itibaren tamamen kent içine yapılmış, ölen kişinin maddi seviyesine bağlı olarak halktan kişiler içinde yapılmaya başlanmıştır. Böylece Roma İmparatorluk Dönemi boyunca "kahramanlık-hero" terimi orijinal anlamını yitirmiş, gelir seviyesi yüksek olan herkes için anıtsal mezar tipi yapılır olmuştur. Ölen kişide artık ailesi tarafından kahraman olarak görülebilir, mezarı da ölen kişinin ailesinin maddi durumuna bağlı olarak bir "heroon" olabilir (Yılmaz 2007: 155) anlayışıyla olanakları el veren herkesin mezarı için bu mimari form kullanılmıştır. Hatta Roma İmparatorluk Dönemi'nde “imparatorluk kültü”yle beraber imparatorlara yapılan mozolelerde birer anıt mezar/heroon özelliği taşımaktadır.

Roma İmparatorluğu'nda Hristiyanlığın kabulüyle beraber, mimari üslupta yeni inancın getirileriyle birlikte paralel olarak değişmiştir. Anıt mezar/heroon anlayışı Klasik Dönem'deki gibi sadece savaş kahramanlarının, Roma İmparatorluk Dönemi'yle birlikte sadece zenginlerin veya asillerin değil, din şehitleri yani martyrlerin gömüldüğü martyriumlar olarak karşımıza çıkmaktadır. Pagandaki kahraman kültü ve onunla birlikte oluşan heroonlar, erken 3. yüzyılla beraber Hristiyan martyr kültünün ve martyriumun kökenini oluşturmuştur.

Hristiyanlık uğruna mücadele verip hayatını kaybeden kişilere yani din şehitlerine "martyr" denir. İşkencelere karşı gösterilen tepki ve din için kurban olmuş kişilerin kahramanlaştırılması martyr kültünü oluşturmuştur (Kazhdan 1991: 1308). Hristiyanlık için şehit düşmüş bir martyrin mezarının üstüne yapılmış anıtsal mimariye de martyrium denilmektedir (Krautheimer 1986: 519). Kutsal insanların yani azizlerin ya da martylerin dünyevi kalıntıları veya onlarla bağlantılı kutsanmış objeler olan rölikler de bu martyriumların içinde muhafaza edilmiştir (Kazhdan 1991: 1780). Martyriumlar retrospektif açıdan incelendiği zaman heroonların nasıl martyriumlara dönüştüğü gözlemlenmiştir. 
Geç Antik Çağ'ın en gözde yapılarından olan martyriumların mimarisine göre sınıflandırılmasına ve dini yapılar ile olan ilişkisine geçmeden önce martyriumları anlamak için martyr kültüne değinmek faydalı olacaktır.

Hristiyanlık dininin tarihçesinde, İmparator Nero (54-68) ile başlayan 313 yılında Licinius ve I. Constantinus tarafindan yayınlanan Milano Fermanı'na kadar olan zaman aralığına, Roma idaresi tarafından Hristiyanlara yapılan topyekûn baskı ve zulümle geçen bir dönem olarak bahsedilir. Kilise öğretilerinin bahsettiği zulümle geçen bu zaman aralığ 1 gerçekten yaşandı mı? Bu dönemde kaç kişi öldürüldü? Hristiyanlığın ilk dönemlerinde oluşan "martyr" anlayışı hakkında sorulan bu ve benzeri soruların cevaplarını bulmak için birçok araştırmalar yapılmıştır. Candida Moss, 2013 yılında yazdığı "The Myth of Persecution: How Early-Christians Invented a Story of Martyrdom?" adlı kitabında, Hristiyanlığın ilk dönemlerindeki Hristiyan martyrleri ve bununla birlikte oluşan martyr kültünü incelemiştir. Moss'a (2013), göre zannedildiği gibi Hristiyanlar Romalılar tarafindan sürekli zulüm görmüyordu. Ayrıca Moss (2013: 14), Constantinus Dönemi'ne kadar çoğu öldürülen kişilerin Hristiyanlık inancı yüzünden değil, politik nedenlerden dolayı idam edildiğini iddia etmektedir. Hristiyanlıktaki şehitlik fikrinin nereden geldiğini sorgulayan Moss (2013: 202), İsa'nın ölümüyle beraber takipçileri tarafından ölümün kutsallaştığını söyler.

Pagan Roma dünyasında yaşayan ve amaçları tek tanrılı, yeni bir din olan Hristiyanlığı yaşamak, yaymak olan martyrlerinde şehitliği, İsa'nın ölümünü taklit etmek olarak algılanmış, İsa'nın açtığı bu yolda yürümek gibi görülmüştür. Bu durum Erken Hristiyanlık sanatında da açıkça görülmektedir. Latincede "bulut" anlamına gelen, resim sanatında ilahi ve dünyevi kudrete sahip figürlerin başını kuşatan çeşitli geometrik formlarda yapılmış şekiller olan hale tasviri, başlangıçta sadece İsa betimlerinde görülürken sonraları martyr betimlerinde de 
görülmesi, din uğruna çeşitli zulümlere tıpkı İsa gibi katlanan ve şehit olan martyrleri bir nevi İsalaştırmak amacının görsel yansımasıdır ${ }^{6}$ (Sunay 2012: 198). İsa ile başlayan bu ölüm olgusu, pagan dünyası için çok yeni olan bu dinin kimliğinin merkezine yerleştirilmiştir. Eusebius'un anlattığı 1-2. yüzyıllardaki Hristiyanlığın uğradığı çileler tablosu Moss'a göre “Zulüm Miti”dir. Bilimsel arkeolojik kazıların ortaya çıkarttığı, martyrlere ait anı yerleri ya da gömüt alanları olan martyriumlar, Hristiyanlığın ilk yıllarında yaşananları "mit" olmaktan çıkarır vaziyettedir. Martyr kültü ister efsane olsun ister gerçek olsun, ölüm üzerine kurulmuş bu din, ölüm kültünü merkezine oturtmuştur ve bu külte ait mimari yapılar olan martyriumlar günümüze ulaşmıştır.

Martyrium kelimesi ilk olarak 4 . yüzyılda Kudüs'te Constantinus tarafından bazilikal planlı olarak yaptırılan kilise için kullanılmıştır (Kazhdan 1991: 1308-1309). Hristiyanlar, martyrlerine atalarının kahramanlarına davrandıkları gibi davranmışlar, onları onurlandırmak için yaptıkları martyriumlar ile onları ölümsüzleştirmişlerdir. Poliycarp Passio'suna (Passio Polycarpi: 18) göre "Smyrna Kilisesi piskoposun kutsal kalıntılara sahipti. Timiotera yani değerli taşlardan daha nadide ve altından daha kıymetli" olarak tanımladığı kemikleri kilisede özel bir bölümde tutulmaktaydı. Buradaki örnekteki gibi din kahramanlarının fiziksel kalıntılarıyla kuracakları temas onun ruhani potansiyelini paylaşıp, öbür dünyadaki ayrıcalığına yaklaşmak anlamına gelmekteydi. $\mathrm{Bu}$ sebeptendir ki din şehidinin ölümünden sonra geriye kalan dünyevi kalıntılarını muhafaza etmek için en uygun yerler martyriumlardır (Colvin 1991: 105).

207 yılları civarında yapılmış 314 yılına kadar kullanılmış olan Callisto katakombunda bulunan iki odayı bazı araştırmacılar martyrium olduğunu düşünmektedir (Krautheimer 1986: 33). Araştırmacılara

\footnotetext{
${ }^{6}$ Ravenna St. Apollinaire Nuovo mozaiklerinden martyrler tasvirleri için bk. Grabar 1953.
} 
katılacak olursak Callisto katakombundaki iki odayı bilinen ilk martyrium olarak kabul edebiliriz. 314 yılından önce az sayıda martyrium bulunmaktadır. İmparator Constantinus ile birlikte Hristiyanlar üzerindeki baskılar sona erince, Hristiyanlık inancına sahip insanlar, inançları için acı çekip ölenlere saygılarını açıkça gösterebilme şansı bulmuşlardır (Colvin 1991: 105).

Antik Çağ'da Hristiyanlıkla birlikte mezarlıklarda oluşan marty kültüyle beraber türeyen martyrium mimarisi zamanla gelişmiştir. Önceleri kendine özgü bir plan bulunmayan martyriumlar 4. yy da ası1 mimari şeklini almıştır. 1949 yılında A. Grabar (1949: 97), martyriumların gelişimi üzerine yaptığı çalışma olan "Martyrium. Recherches sur le culte des reliques et l'art chretien Antique"de Erken Hristiyanlık dönemi kült yapılarından olan martyriumların, diğer yapılardan işlevine göre ayrılmış, kendilerine has bir mimariyi ortaya koyduklarını söylemiştir. Dini yapılardan bağımsız gelişen martyriumların tonozlu, merkezi planlı, kare, haç, dairesel veya çokgen planlı, oldukça basit biçemli olduklarını söyleyen Grabar (1949: 96), ilk zamanlarda dini yapıyla keskin bir şekilde ayrı geliştiklerinden bahseder. Martyriumların, pagan anıt mezarlarının bir devamı olarak geliştiğini söyleyen Grabar'a karşılık Ward-Perkins (1994: 489-490), yaptığı çalışmada Grabar'ın plan özelliklerine göre sınıflandırdığ 1 martyrium planlarından bazılarının Constantinus'tan önce var olmadığını ifade eder ve martyriumlara pagan anıt mezarlarından başka bir yapının öncülük etmiş olabileceğini öne sürer. Krautheimer (1986: 77), 1986 yllındaki "Early Christian and Byzantine Architecture" çalışmasında martyrium mimarisinin ortaya çıkışına ve gelişimine Roma İmparatorluk mimarisinin kaynaklık ettiğini, birinci yüzyılda saray ya da konutların giriş bölümlerinde yer alan ve sıkça rastlanan dairesel, sekizgen ya da üç yapraklı yonca tipinde plana sahip salutatoriumlar (kabul salonu) gibi bölümlerin ya da triclinium (yemek salonu) bölümlerinin martyrium plan gelişimi için önemli rol 
oynadıklarını belirtir ve Septimius Severus'un 2. yüzyıldaki tonozlu ve çokgen planlı taht odasını bu duruma örnek göstermiştir. Ayrıca Nero'nun altın evindeki sekizgen triclinium, kışlık taht ve ziyafet odası olarak tasarlanmış ongen Minerva Medica ve Constantinopolis'teki Antiochos Sarayı'nın konuk salonunu da Krautheimer'ın örnekleri arasinda bulunmaktadir (Krautheimer 1986: 78).

Martyriumların mimari gelişim süreci incelendiğinde, ilk ortaya çıktıklarında heroon kültüyle beraber pagan anıt mezarlarından etkilenmişlerdir. Mimari plan özelliklerinde ise Geç Roma İmparatorluk saraylarındaki kabul salonları ya da resmi ziyafet salonları olan tricliniumlardan etkilendikleri gibi şüphesiz imparatorluk mozoleleri de diğer etki alanları olmalıydı. Dıştan sekizgen, içten yuvarlak planlı, kubbeyle örtülü, Constantinus öncesine ait Diocletianus mozolesi, Constantinus Dönemi ve sonrasına ait olan Roma'da Constantinus için yapılan fakat annesinin gömülü olduğu SS. Marcellino mozolesi (Colvin 1991: 111), İmparator Honorius'un Roma St. Peter'deki mozolesi, Kudüs'teki Anastasis Rotondu'nun bir benzeri olan Constantinus'un kızı için yapılan S. Agnese yakınlarındaki Constantina Mozolesi (Colvin 1991: 111), yuvarlak plan ve kubbeli örtülü bir plan anlayışı içerisinde inşa edilmişlerdir. Constantinus Dönemi ve sonrasında yapılan mozoleler, pagan imparatorluk kültü mozolelerine göre değişiklik göstermiştir (Krautheimer 1986: 64). Bu dönem mozoleler tek en önemli yapı olmaktan çıkmış, mezarlık bazilikalarının yanına eklenmiştir. Tıpkı kiliselerin belli bölümlerine ya da yanlarına yapılan martyr mezarları gibi dini yapının yanına konumlanmışlardır. İmparatorluk mozoleleri de martyriumların mimari oluşumunda salutatoriumlar, tricliniumlar gibi etkili olmuşlardır.

Mimar Ayça Beygo'nun (2006: 44-45), 2006 yılında martyriumlarla ilgili hazırladığı tez çalışmasında, martyriumları tarihsel açıdan "Constantinus Dönemi" ve "Constantinus Dönemi Sonrası" olarak sınıflandırmıştır. Doğu ve Batı martyriumları olarak ayrı ayrı 
incelendiğinde farklı gelişim gösterdikleri gözlemlemiş, Doğu'da kutsal topraklarda ortaya çıkan dairesel planlı martyriumlar baz alınarak geliştikleri söylemiştir. Önemi artan ve işlevi belirginleşen martyriumlar imparatorluğun doğusuyla batısı arasında farklı bir gelişim göstermiştir (Ward-Perkins 1994: 495).

Çalı̧̧mamızda martyrium yapıları, plan özelliklerine göre örneklendirilmesinin yanı sıra dini yapıyla olan ilişkileri açısından da incelenmiştir. Dini yapıdan bağımsız ve dini yapı kompleksi içinde olarak iki başlık altında incelenmek istenmiş fakat zamansal ilerleme boyunca bu iki yapıyı ayrı tutmak neredeyse imkânsız olmuştur. Bu yüzdendir ki ilk başlıkta martyriumları mimari tiplerine göre ele alıp örneklerdirdikten sonra ikinci başlıkta kilise ile olan ilişkileri çeşitli örneklerle birlikte anlatılmaya çalışılmıştır.

\section{Martyrium Yapılarının Mimari Tipleri}

Hristiyanlık mimarisinde İmparator Constantinus'un yaptırdığı bazilikal planlı kiliselerin yanı sıra merkezi planlı yapılarda yapılmıştır. Kaynağını Roma İmparatorluk kabul salonları, imparatorluk kültü mozolelerinden alan merkezi plan genellikle martyrium mimarisinde uygulanmıştır (Roth 2018: 337). 4. yüzyılda İmparator Constantinus'un Hristiyanlara sağladığı din özgürlüğü ile beraber yer üstüne avlulu, anıtsal, merkezi planlı martyriumlar yapılmaya başlanmıştır. İçerisinde martyrin mezarı veya rölikleri bulunan martyriumlar ilk başlarda dini bir yapı kompleksinden ayrı olarak yapılmıştır. İmparator Diocletianus tarafindan şehit edilen Aziz Anastasius'un Salona Marusinac'taki martyriumu, Constantinus Döneminden önce marty mezar mimarisinden günümüze ulaşan nadir örneklerden biridir ve dini bir yapıdan bağımsız olarak yapılan ilk martyrium örneğidir (Ward-Perkins 1994: 499). İki katlı olan yapının tonozlu ilk katında martyrin mezarı bulunmaktadır. Muhtemelen cenaze yemekleri ve ayinler için kullanılan üst oda beşik tonozludur (Krautheimer 1986: 35). 
Erken Hristiyanlık Dönem'inde Constantinus'la beraber daha da belirginleşerek ortaya çıkan kutsal alan kültünü yaşatan martyriumlar kiliselerden bağımsız bir şekilde gelişerek kendi mimari düzenini ortaya çıkarmıştır. Tonozlu, merkezi planlı, kare, haç, dairesel ve çokgen planlı olarak çok çeşitli versiyonlara sahiptirler (Grabar 1949: 96). Merkezi planlı martyrium yapılarının içinde yuvarlak halka oluşturacak vaziyette sütun dizilimi bulunur ve çoğunlukla kubbe ile örtülüdür (Eyice 1988: 46). Bu merkezi planlı yapılar bazilikal plana nazaran daha geniş çeşitliliğin uygulanabilirliğini sağladığı için muhtelif uygulamaları yapılmıştır.

\section{Merkezi Planlı Dairesel Martyriumlar}

Merkezi planlı dairesel formda yapılmış martyriumlara kaynaklık etmiş olabilecek yapılar şüphesiz Roma İmparatorlarının ailelerine ait mezar yapıları olan imparatorluk mozoleleridir. İmparator Constantinus'un kızına ait olan S. Costanza mozolesi, dairesel planl, çevre koridorlu, kubbeli bir yapı olma özelliğiyle, merkezi planlı dairesel martyriumlara öncülük etmiş imparatorluk mozolelerinin en iyi örneğindendir ${ }^{7} .350$ yıllarında bağımsız bir yapı olarak tasarlanan mozolenin yanına daha sonradan kilise inşaa edilmiştir (Resim 3). S. Agnese'deki S. Costanza mozolesi bir martyre ait olmasa da martyrler için yapılmış dairesel formdaki martyriumlara mimari anlamda öncülük etmiştir.

Kudüs'teki Yeniden Diriliş Kilisesinde bulunan ve İsa'nın göğe yükselmesini simgeleyen Anastasis Rotondası da merkezi planl, dairesel formda yapılmış martyriumların kutsal topraklardaki örneğidir (Krautheimer 1986: 60). İmparator Constantinus dönemimde yapımına başlanan Yeniden Diriliş Kilisesi'nin batısına konumlanan martyriumun, kiliseden önce mi sonra mı yapıldığı tartışma konusu olsa

${ }^{7}$ S. Constanza için bk. Krautheimer 1986: 65. 
$\mathrm{da}^{8}$ kilise ve kilise mimarisinden bağımsız olarak yapılmış merkezi planlı bir martyriumun tümleşik olarak kullanıldığı örnekler arasındadır. Merkezi planlı, dairesel formdaki, kubbeli martyriumu, duvarları dıştan çokgen, iç yüzeyinden de yuvarlak olan çevre koridoru çevrelemektedir. Koridorun doğu, batı ve kuzey yönlerinde küçük apsisler bulunmaktadır (Couasnon1974: 26; Koch 2015: 51, res.: 9 lev.: 1,2.).

İmparatorluğun batısındaki $\mathrm{S}$. Constanza ve doğusundaki Yeniden Diriliş martyriumu merkezi planl, dairesel formlu, kubbeli yükselişleri ve çevre koridorlarıyla Anadolu'daki birçok martyriumlara referans olmuşlardır.

Günümüzde Aziz Menas Kilisesi'nin altında kalmış, var olduğu dönemde Psamathia (Samatya) diye bilinen mevkiide bulunan, 4-5. yüzyıla tarihlenen Aziz Karpos ve Papylos ${ }^{9}$ martyriumu ise dairesel planlı ve 5. yüzyıla tarihlendirilmiş̧ir (Schneider 1936: 1). 1935 yılında yapıyı ilk çalışan A. M. Scheneider (1936: 1) $12 \mathrm{~m}$ çapında, 5m yüksekliğinde yuvarlak olan mekânı $2,50 \mathrm{~m}$ genişliğinde, $7.50 \mathrm{~m}$ yüksekliğinde üzeri beşik tonozla örtülmüş bir çevre koridoru tarafından çevrelendiğini kayıtlara geçmiş̧ir (Resim 4). Doğu kısmında apsis ve onun kuzeyindeki yan odadan bahseder. Mimar Beygo'da (2006: 5, res.: 2.7-2.10) yaptığı tez çalışmasında ölçüleri doğrulayıp, iç mekandaki ufak tefek değişiklikler haricinde temel planın aynı kaldığını söylemektedir.

8325 yılındaki İznik konsilinde Kudüs piskoposu Macarius Aphrodite tapınağının altındaki İsa'nın mezarını çıkartıp, bir mezar yapısının içine konulmasını talep etmiştir. Bu talep karşılığında İmparator Constantinus mezarı çıkartmıştır. Ancak 333 yılında bazilikal planlı kilisenin inşaatı tamamlanmıştır. Kilisenin inşaatı boyunca mezar bir avlu içinde barındırılmıştır (Couasnon 1974: 12-14).

${ }_{9}$ Piskopos Karpos ve yardımcısı Papylos, İmparator Decius (249-251) zamanında Bergama'da, Hristiyanlık'tan vazgeçmedikleri için, Asya başkonsülü tarafından yakalanıp işkenceye tabi tutulmuşlar ve diri diri yakılarak öldürülmüşlerdir. Kalıntıları Hristiyanlar tarafindan saklanmak ve anılmak üzere toplanmıştır (Beygo 2006: 38-39).

Uludağ Üniversitesi Fen-Edebiyat Fakültesi Sosyal Bilimler Dergisi Uludağ University Faculty of Arts and Sciences Journal of Social Sciences

Cilt: 21 Sayl: 39 / Volume: 21 Issue: 39 
Merkezi planl, daire biçimde tasarlanmış martyriumlara bir örnek teşkil eden ve günümüzde İstanbul'daki Şehzade ve Laleli mevkiileri arasında bulunan Balabanağa Mescidi'dir. Mescid üç yapım evresi geçirmiştir (Mansel 1936: 65). Birinci evresinde dışarıdan dairesel planlı, doğu kısmında apsis çıkıntısı olan, içerisinde altı adet mezar hücresi bulunan bir martyriumdur (Resim 5). Gurlitt'in çizimlerinde bu altı adet hücreler arcosoliumlu mezar düzenlemesi olarak görülür (Gurlitt 1907: 42) fakat A.M. Mansel'in 1930 y1llarında yaptığ 1 kazılarda bu arcosoliumlu mezar düzenlemeleri ile karş1laşılmamış sadece bu altı adet hücrenin altına denk gelecek şekilde konumlandırılmış mezarlar bulunmuştur (Mansel 1936: 51-52). Birinci evrede yap1 5 yüzyıla ait dairesel planlı, iç kısmında altı adet arcosolium mezar düzenlemeli, iç düzenlemesi mermer plakalarla kaplı, yüksek kubbeli bir martyriumdur. İkinci evrede daha özensiz taşlarla tekrar inşaa edilmiş $4.45 \times 3.20 \mathrm{~m}$ ölçülerinde dikdörtgen planda, iskeletleri rutubetten korumak için yapılmış zeminden $0,65 \mathrm{~m}$ yükseklikte ahşap zemini bulunan, üst yapısı basık kubbeli ve bu kubbenin tam ortasında denk gelen havanladırma açılığı bulunan ve ilk evrede mermerle kaplı iç dekorasyonu bu evrede sökülmüş yerine alçı sıva yapılmış olan mezar odası olarak hizmet vermiştir (Mansel 1936: 61). Üçüncü evrede ise Anadolu'ya Türklerin gelmesiyle birlikte, İslamlaşarak mescide dönüşmüştür (Mansel 1936: 65). Mescidin ilk evresindeki martyrium binasinda, Aziz Karpos ve Papylos martyriumunda $^{10}$ olduğu gibi doğuya doğru apsis çııntısı

10 Aziz Karpos ve Papylos martyriumunda bulunan fresk Prof. Dr. M. Sayar'ın belirlemelerine göre 9-11. yüzyıla tarihlenmektedir (Beygo 2006: 27). Duvar yapısının yuvarlak ana mekândakinden daha farklı olması ve tonozunun üzerindeki freskteki yazıtın 11. yüzyıla tarihlenmesinden dolayı daha sonraki dönemlerde bu bölümün genişletilmiş olabileceğinin göstergesi olarak yorumlayabiliriz. 
bulunmaktadır. Her ikise de bu özelliğiyle 4. yüzyıla tarihlenen Kuzey Filistin'deki Beth Shean ${ }^{11}$ martyriumuna benzer.

Günümüzde İstanbul Bakırköy civarında, Doğu Roma İmparatorluğu döneminde Hebdomon diye bilinen mevkiide yer alan Hebdomon Martyriumu da diştan dairesel planlıdır (Resim 6). 20. yüzyılın başlarında Macridy Bey tarafından kazısı yapılan martyrium (Macridy ve Elbersolt 1922: 363), Balabanağa Mescid'inin ilk evresindeki martyrium yapısı ve Aziz Karpos ve Papylos Martyrium'u gibi dıştan dairesel biçimlidir. Fakat içten haç şeklinde dörde ayrılmıştır. Bu özelliğiyle diğer ikisinden ayrılmaktadır. Dıştan Çapı $16.35 \mathrm{~m}$ olan Hebdomon martyriumunun içten dörde ayrırarak oluşturulan haçvari formun dört koluna denk gelen ve aynı zamanda binanın üst yapısı olan kubbeyi taşıyan pilyelerin içlerinde lahitler bulunmaktadır (Macridy ve Elbersolt 1922: res.: 14-15; Mansel 1936: 66). Hebdomon martyriumunda da Aziz Karpos ve Papylos martyriumunda olduğu gibi 3 metre yüksekliğinde, 0.60 metre genişliğinde olan çevre koridoru bulunmaktadır (Mansel 1936: 66).

Constantinople'de bulunan Blakhernai bölgesinde inşaa edilmiş olan Azize Maria Kilisesi yanındaki martyrium dairesel formlu martyriumlara örnek teşkil eder (Krautheimer 1986: 105).

Günümüzde Kadıköy bulunan Azize Euphemia Kilisesi'ndeki martyriumu, var olan bazilikanın koridorlardan birinin sonuna bulunmaktadır (Krautheimer 1986: 105). Hristiyan âlemi için önemli bir azize olan Euphemia, Chalcedon'da tanrı Ares adına düzenlenen pagan bir festival katılmayı red ettiği için çeşitli işkencelere tabi olarak 307 yılında şehit edilmiştir (Karlin ve Hayter 1995: 404). Tios'lu Constantinos'tan öğrendiğimiz kadarıyla Chalcedon'da şehit edilen Eupheima'nın bedeni Chalcedon'da kendi adına yapılan bir kiliseye

${ }^{11}$ Beth Shean martyriumu için bk. Krautheimer 1986: 75.

Uludağ Üniversitesi Fen-Edebiyat Fakültesi Sosyal Bilimler Dergisi Uludağ University Faculty of Arts and Sciences Journal of Social Sciences

Cilt: 21 Sayl: 39 / Volume: 21 Issue: 39 
konulmuştur (Akyürek 1998: 176). Azizenin yaşadığı işkenceler çeşitli kaynaklarda bahsedilmektedir ${ }^{12}$. Anlatılan bu işkenceler kuşkusuz daha sonraki zamanlarda kült amacı yaratmak için abartılmış olsa da önemli olan böyle bir azizenin pagan Romalılar tarafından öldürülmüş, adına kilise yapılmış, mezarı ve çeşitli rölikleri bu kiliseye konmuş olmasıdır (Akyürek 1998: 177). Evagrios'un anlatımına göre, "Euphemia Kilisesi" bazilikal planlı bir kilisedir. Bazilikal planlı bu kilisenin kuzey tarafina bitişik olarak merkezi planlı dairesel formlu ve orta sahına bakan galerili yapı, azizenin gümüş tabut içindeki röliklerinin saklandığ 1 martyrium bulunmaktadır (Mango 1986: 30, dipnot.32). Yekpare bir yap1 olan martyriuma giriş kilisenin içindendir (Milburn 1988: 124). 4. yüzyılın sonlarına doğru azize Euphemia adına adanmış kilisenin kuzey nefine bitişik vaziyette, içerisinde azizenin röliklerinin bulunduğu gümüş bir tabut bulunan martyrium tıpkı Kudüs'teki "Yeniden Doğuş Kilisesi" ve Constantinus, Thedoros II Kiliseleri ve Azize Maria Kiliseleri yanındaki dairesel martyrium yapıları gibi bazilikal planlı kilise ile aynı kompleks içindedir.

\section{Merkezi Planlı Çokgen Martyriumlar}

Merkezi planlı çokgen martyriumlar, bütün bir merkezi alan, çokgen kenarlı bir formda düzenlenerek ve bu çokgen bir düzeneğin üstüne oturan kubbe ile örtülü bir mimariye sahiptir. Merkezi planlı çokgen martyriumlar bazen sekizgen ya da altıgen bazende üç yapraklı yonca tipi veya dört yapraklı yonca formda karşımıza çıkmaktadır.

Merkezi planlı çokgen form mimarisi ilk olarak 1. yüzyılda Domus Aurea (Antiocheia ad Orentem) ile Domus Augustana gibi saray kompleksleri içinde görülür. 2. yüzyılda ise Ostia'da, Forum Hamamları ve Kartaca'daki Antoninler Hamamları'nın sıcaklık

\footnotetext{
12 "Kırbaçlanma, hapsedilme, çarka bağlanma, ateşe atılma, eziyet, vahşi hayvanlara atılma, sivri şişlerle şişlenme ve kızgın ateşe atılma.
} 
bölümleri sekizgen planlıdır. Bağımsız bir şekilde yapılmış çokgen planlı yapıların en erken örneği ise 2. yüzyıla tarihlenen Hadrianus Villası'ndaki Piazza d'Oro vestibülüdür (Ward-Perkins 1994: 110). Bu plan tipi erken dönemlerde ev mimarisinde ya da haman mimarisinde kullanılmış, 3-4. yüzyılla birlikte anıtsal bir mimariye geçmiştir. Bu duruma örnek olarak Selanik'teki 3. yüzy1la tarihlenen, merkezi planlı sekizgen formlu Galerius Rotundası gösterilebilir (Vickers 1973: 115). Geç Antik Çă̆ Erken Hristiyanlık mimarisinde ise çokgen form genellikle vaftizhanel ${ }^{13}$ ve martyriumlarda kullanılmıştır. Vaftizhanelerle martyriumların birlikteliği tamda bu noktadadır. Her ikisin de merkezi planlı yuvarlak form ya da çokgen planlı form kullanılmışıtır. Ayrıca Paulus'un Roma ve Colose halkına yazdığ 1 mektupta vaftizi, İsa ile ölümde ve dirilişte entegre olmak, ölümde ve dirilişte birlikte olmayı kabul etmek olarak tarif eder (Romalılar Bap. 6, 3-6; Koloseliler Bap. 2, 12). Bunun içindir ki antik dünyanın mozolelerinin planı vaftiz yapılarına uygulanmıştır (Delvoye 1966: 463; Davies 1980: 200). Ayşe Aydın (2006: 2), yazmış olduğu "Kilikya ve Isaurya Vaftiz Yapıları" adlı makalesinde bu bütünleşmeye değinmiş, mezar yapılarının vaftiz binalarına, mezar odalarının içindeki lahitlerinde vaftiz havuzlarına dönüşümlerinden bahsetmiştir. Vaftizhanelerle aynı mimari plana sahip olan merkezi planlı çokgen martyriumlar, bazen altıgen bazen de sekizgen formda ya da üç yapraklı yonca ve dört yapraklı yonca formda karşımıza çıkar.

Hristiyanlığın batı dünyasında da altıgen formda martyrium yapılarına örnekler bulunmaktadır. Örneğin 4. yüzyılın ikinci yarısına tarihlenen Aziz Praetextatus katakompu üzerindeki martyrium altıgen

13 İlk olarak 315 yılında Constantinus tarafından inşaa ettirilmiş "Lateran Vaftizhanesi" için bk. Krautheimer 1986: 90; Brandt 2006: 222; yine erken örneklerden Ravenna'daki Ortodoks Vaftizhanesi için bk. Bottari 1960: 7; Mazotti 1961: 255; Constantinople'deki Aya Sofia'nın vaftizhanesi bk. Van Millingen 1912: 78. 
formda, orta mekânı kubbeli ve apsisli bir yapıdır. Salona şehrinde büyük bazilikanın yanında bulunan altı köşeli kubbeli mezar odası da merkezi planlı altıgen formda yapılmış martyriumlara örnek olarak verilebilir. Constantinopolis'te bulunan Antiokhos Sarayı'nın konuk salonu altıgen formdadır. 6. yüzyılda kiliseye dönüştürülmüş ve Azize Euphemia'nın rölikleri bulunduğu martyriumdan alınarak buradaki altıgen planlı bu yapıya taşınmıştır (Kazhdan 1991: 747).

Hristiyanlıkta kutsal olarak kabul edilen sekiz sayısı, Petrus'un mektubunda bahsettiği Eski Ahitte geçen Nuh'un Gemisi'nden kurtulan sekiz kişiyi simgelemektedir (Tekvin Bap.7, 13; Petrus'un I. Mektubu Bap. 3, 20-21). Eski dünyadaki yedi gün, İsa'nın dirildiği sekizinci gün ile yenilenmiştir (Davies 1980: 200; De Chapeaurouge 1991: 76; Dölger 1934: 153 vd.; Heiser 1987: 147 vd.). Bu sebepledir ki kutsal sekiz, sekizgen formuyla vaftizhanelerde kullanılmıştır (Aydın 2006: 4).

Aynı sebeplerden dolayı bu form, hem Doğu Hristiyanlıkta hem de Batı Hristiyanlıkta, inancı yüzünden ölümü göze alan martyrlerin mezar yapılarında da kullanılan formlardan olmuştur. İmparatorluğun doğusunda bulunan bazı martyriumlarda sekizgen formun uygulandı görülmektedir. Örneğin Bethlehem'deki Doğuş Kilisesi'nde bulunan martyrium merkezi planlı sekizgen formludur (Krautheimer 1986: 60). Ayrıca Kudüs'teki Yükseliş Kilisesi'inde bulunan martyrium sekizgen formdadır (Grabar 1949: 97). Moritanya Blad Guitoun bat1 nekropolünde bulunan, sekizgen formda, ion düzeninde anitsal kapısıyla pagan özellikleri taşıyan martyriumda merkezi planlı sekizgen formlu martyriumların imparatorluğun doğusunda bulunan martyrium örnekleri arasında gösterilebilir (Colvin 1991: 102-103). İmparatorluğun kutsal olarak kabul edilen topraklarındaki bu martyriumlar 4. yüzyıla tarihlenen eş zamanlı yapılmış martyriumlardır. İmparatorluğun batısında ise 5. yüzyıla doğru inananların martyr mezarlarının yanında yemek törenlerinin yapılmasına getirilen yasakla 
birlikte martyr röliklerinin din adamalarının koruyuculuğunda normal kiliselerde aktarılmasına ve böylece piskoposluk litürjisiyle birleşip, daha güçlü bir merkez yaratılmasına sebep olmuştur (Brown 1982: 34$37)$.

Hemen hemen her kilisede martyr röliklerini barındırma isteği ve röliklerin nakli 450 yılından sonra sıklıkla karşılaşılan durum haline gelmiştir (Krautheimer 1986: 97). Böylece imparatorluğun batısındaki Phillippi'de bulunan "Sekizgen Kilise" gibi martyrium plan şeması normal kiliselerde de kullanılmaya başlanmıştır ${ }^{14}$. Aynı zamanda imparatorluğun doğusunda da röliklerin normal kiliselerde naklinin artması, kutsal sayılan martyr mezar yapılarının yapılmasına engel olmamıştır (Grabar 1949: 103).

Nyssa'lı Gregorios'un Ikonium piskoposu Amphlikios'a yazdığ bir mektupta tarif ettiği ideal martyrium planındaki gibi Binbir Kilise 8 Nolu (Grabar 1946: 80, 414, 417, lev.: IV-V.; Eyice 1971: 30, res.: 4654) yapı da tıpk1 aynı döneme ait Nyssa'daki (Koch 2015: 47, res.: 22) martyrium yapısı gibi sekizgen formludur.

Constantinople'te bulunan Azize Maria Khalkopratiae Kilisesi yanındaki martyrium yapısı merkezi planlı sekizgen formlu martyrium yapisidir (Mathews 1976: 319).

Hierapolis'teki Philippus Martyriumu merkezi planlı sekizgen formdadır (Koch 2015: 49, res: 25). Kentin pagan nekropol alanın içindeki düzlüğe kurulmuştur (D'Andria 2010: 184). Merkezi planlı sekizgen formlu yapısı açık dörtgen bir ve dört kenara yaslanmış 32 odadan ve 4 adet şapelden oluşan bir yapı kompleksiyle çevrilidir (D’Andria 2010: 188, res.: 160-161) (Resim 7).

${ }^{14}$ Phillippi sekizgen kilise için bk Krautheimer 1986: 128-130.

Uludağ Üniversitesi Fen-Edebiyat Fakültesi Sosyal Bilimler Dergisi Uludağ University Faculty of Arts and Sciences Journal of Social Sciences Cilt: 21 Sayı: 39 / Volume: 21 Issue: 39 
Constantia'daki bulunan yapı merkezi planlı sekizgen formlu bir yapıdır (Resim 8) (Keser Kayaalp 2013: 422). Martyriumlar başlığı altında ele aldığımız yapı, Grabar'ın martyrium örnekleri arasında yerini alamasa da (Grabar 1946; Keser Kayaalp 2013: 422) 2013 yılında E. Keser Kayaalp'in (2013: 426, res.: 10) yaptığı çalışmada Aziz Thomas'a ithaf edilmiş bir martyrium yapısı olduğu söylenmektedir.'

Leontopolis (Zengibar Kalesi) bulunan yapıda merkezi planlı sekizgen formludur. Ana kayaya oyulmuş çift basamaklı bir podium üzerine yapılmıştır (Koch 2007: 257). Anadolu'da bulunan merkezi planlı sekizgen formlu yapılara örnek teşkil etmektedir (Resim 9). 4-5. yüzyıla tarihlenen yapı, bir martyrium mu değil mi tam olarak bilinmese de gerek sekizgen formu gerekse doğusunda bulunan apsisi ve aynı Hierapolis Martyrium'unda gibi merdivenli bir platformun üzerine yapılmış olması buranın Hristiyanlığa ait martyrium olduğu düşündürebilir. Yalova'da bulunan sekizgen planlı yap1 da Leontopolis'teki örnek gibi martyrium yapısı olarak düşünülebilir (Limberis 2011: 76, res.: 6).

Merkezi planlı çokgen formlu martyriumlar başlığı altında incelediğimiz üç yapraklı veya dört yapraklı yonca form tipi de Roma mimarlı̆̆ının ilk olarak konut mimarisinde görülmüştür (Lavin 1962: 4 vd.). 4. yüzyılın sonlarına doğru Afrika'da oldukça çok kullanılması, bu tiplerin bölgenin spesifik bir mimarisi olarak anılmasına yol açmıştır (MacDonald 1986: 277) Geç dönem aristokrat sınıflarına ait konut mimarisi olabileceği şeklinde yorumlanmaktadır (Ward-Perkins 1994: 460 vd.). Örneğin Afrika etkisiyle yapılmış 330-320 yıllarına ait Piazza Armerina Villası'nın (Sicilya) triconchusu bu duruma örnek teşkil etmektedir ${ }^{15}$. Kökeni olan Afrika'dan yayılımı ile birlikte 5. yüzyılda üç yapraklı yonca formu kiliselerde ve martyriumlarda kullanılmaya başlanmıştır. Resafa'daki yapıyı dört yapraklı yonca formlu martyrium

${ }^{15}$ Piazza Armerina Villası için bk. Bayülgen 2012: 63.

Uludağ Üniversitesi Fen-Edebiyat Fakültesi Sosyal Bilimler Dergisi Uludağ University Faculty of Arts and Sciences Journal of Social Sciences

Cilt: 21 Sayı: 39 / Volume: 21 Issue: 39 
olarak kabul eden Guyer, üç yapraklı yonca ve dört yapraklı yonca formlarının uygulandığı yapıların işlevini gömüt yapıları olarak tahdit etmiştir (Spanner-Guyer 1926: 56 vd.). Ama daha sonraki yıllarda olan çalışmalar Guyer'in bu savını çürütmüş, bu tarz formdaki yapıların normal kiliselerde de görüldüğünü ortaya koymuştur ${ }^{16}$. Üç yapraklı yonca form, merkezde oluşan kare bir alanın etrafının üç yarım daireyle çevrelendiği bir plandır. Merkezi bir plan çerçevesinde, eşit büyüklükteki ve yarım daire şeklindeki üç yaprak (konkhos) yer almaktadır (Aydın 2005: 244; Deichmann 1954: 944). Bu form Geç Antik Çağ Erken Hristiyanlıkla beraber çeşitli yapılarda görülmektedir (Mercangöz 1990: 126).

Vaftizhane, saray kabul salonları, kiliselerde görüldüğü gibi martyrium yapılarında da kullanılmıştır (Aydın 2005: 244; Mercangöz 1990: 126). Günümüzde Macaristan sınırları içinde bulunan Sopianae'de (Pécs) Geç Antik Çağ Erken Hristiyan dönemine ait üç yapraklı yonca planlı mezar yapisi bulunmaktadır (Brenk 1980: 313314. sek. 98, 99, res. 384).

Üç yapraklı yonca formu, Sardes'teki Antonia Claudia Sabina mezar yapısındaki kullanımı, mezar yapılarındaki kullanımın erken örneklerinden biridir (Butler 1913: 477; Ward-Perkins 1966: 297, dip not 3). Genellikle pagan mezar yapılarında görülen bu form, Erken Hristiyanlıkla beraber daha çok kilise mimarisinde, şapellerde (Aydın 2005: 244; Harrison 1963: 149; Stollmayer 1999: 135) uygulansa da martyrium yapılarında da kullanıldığını görebiliriz. Örneğin Bosra, Ohrid (Makedonya), Lin (Arnavutluk) ve Apameia (Suriye) 6. yüzylla tarihlenen üç yapraklı yonca formunda martyrium örnekleri bulunmaktadır (Koch 2015: 50). Olympos'taki piskoposluk kilisesinin ek yapısı üç yapraklı yonca planlı yapı martyrium ya da vaftizhane

\footnotetext{
${ }^{16}$ Trikonkhos planlı kiliseler için seçilmiş bazı örnekler için bk. Pekak 2010; Jacobek 1994; Dört yapraklı yonca planlı kiliseler örneği için Bonnet 2008; Özcan 2006.
} 
olarak düşünülmektedir (Parman 2001: 137-144, Çiz.: 1; Olcay Uçkan 2008: 53). Ayrica Priene, Antiochia ad Cragum ve Perge kentlerinde de üç yapraklı yonca formunda yapılar bulunmaktadır fakat martyrium yapısı olup olmadıkları belirlenememiştir (Koch 2015: 50).

Dört yapraklı yonca form ise, merkezde oluşan kare bir alanın etrafının dört yarım daireyle çevrelendiği bir plandadır. Merkezi bir plan çerçevesinde eşit büyüklükteki ve yarım daire şeklindeki dört yaprağın (konkhos) yer almaktadır. Kissebükü'ndeki 2 numaralı bazilikanın yanında bulunan martyrium da merkezi planlı dört yapraklı yonca planlı martyriumlara örnektir (Ruggieri 2003: 174-180, Pl. 2324).

1930 y1llarında bulunan ve 5. yüzyıla tarihlenen Seleucia Pieria'daki martyrium yapısı da merkezi planlı dört yapraklı yonca formludur (Campbell 1941: 57-71) (Resim 10). 36 m çapında olan yapının doğusuna doğru derin bir apsis bölümü bulunmaktadır. Krautheimer (1986: 138) yapıyı, Theotokos Kilisesiyle karşılaştırıp, kilise gibi bağımsız merkezli planlı, çift kabuklu olduğunu ve büyük bir ihtimalle martyrium yapısı olduğunu söylemektedir (Koch 2015: 51, res.: 27).

2016 yılında Hatay Müze Müdürlüğü başkanlığında, Hatay İli, Defne İlçesi, Armutlu Mahallesinde yapılan kurtarma kazılar sonucunda, Seleucia Pieria'daki martyrium yapısına benzer; merkezi planlı, dört yapraklı yonca formlu martyrium yapısı bulunmuştur (Aydın Çilingir 2017: 189-202, res.: 4, çiz.: 3) (Resim 11).

1991-1992 yıllarında, Gültepe Park alanında Kocaeli Müzesi bakanlığında yapılan kurtarma kazıları sonucunda erken dönemden Geç Antik Çağ'a kadar buluntuları bulunan nekropol alanı içerisinde tespit edilen martyrium yapısı da merkezi planlı, dört yapraklı yonca formludur (Resim 12) (Demir 1993: 357-377, plan: 3). Burada bulunan martyrium yapısındaki yonca yapraklarının Seleucia Piera'daki 
martyriumun yonca yapraklarına göre daha dar ve dişarıya daha taşkın bir vaziyette bir plan çizmesi açısından Sırbistan Niş Çariçingrad Martyriumu'na benzemektedir (Resim 13). Her iki martyrium yapisının etrafinda yapı ile bağlantılı mezar odaları bulunmaktadır ${ }^{17}$. Dört yapraklı yonca formu hem martyriumlarda hem de saray kiliseleri ve katedrallerde kullanılan bir plan çeşididir (Krautheimer 1986: 97).

\section{Haç Planlı Martyriumlar}

Erken Hristiyanlıktan bu yana Hristiyanlık dini için kutsal olan haçın formu, mimari düzenlemelerde oldukça fazla uygulanmıştır. Haç formu, Hz. İsa'nın tekrar yeryüzüne ineceği ve ölülerin tekrar dirileceği günü kutsal haçın koruyuculuğu altında bekleme isteğinden dolayı mezar odalarında özellikle de Hristiyanlık dini uğruna şehit edilenlerin veya azizlerin gömüldüğ̈̈ martyriumlarda tercih edilen bir plan türü olmuştur (Ramsey ve Bell 1909: 345-346; Davies 1952: 74-75; Stanzl 1979: 56).

Costantinople'de İmparator Constantinus'un kendi mezarı için yaptırdığı, daha sonraları yanına toplantı salonları, havuzlar, çeşmeler eklenerek büyük bir kompleks haline gelen On İki Havariler Kilisesi başlangıçta haç planlı bir martyriumdu (Ward-Perkins 1994: 513). Eusebius'un yazılarından öğrenildiği üzere haç planlı olup dört kolun kesişim yeri olan merkezde, sütunlarla çevrili lahitte imparatorun mezarı bulunmaktaydı (Krautheimer 1986: 68).

Nyssalı Grerorios'un, Ikonium piskoposu Amphilokhios'a yazdığı bir mektupta inşaa edilecek bir martyriumla ilgili olarak "haça benzemesi" hakkında görüş bildirmiştir (Mango 1986: 15-16). 380 yıllarındaki Grerorios'un talebinden de anlaşılacağı üzere kutsallık sembolü olan haç erken dönemlerde bir plan tipi olarak martyrium mimarisinde kullanılmıştır (Pekak 2008: 87).

${ }^{17}$ Niş Çariçingrad Martyriumu için bk. Eyice 1952.

Uludağ Üniversitesi Fen-Edebiyat Fakültesi Sosyal Bilimler Dergisi Uludağ University Faculty of Arts and Sciences Journal of Social Sciences Cilt: 21 Sayl: 39 / Volume: 21 Issue: 39 
380 yılına tarihlenen ve Filistin'de bulunan Aziz Lakobus'un martyriumu da erken dönem haç planlı bağımsız martyriumlara örnek teşkil eder. İlk önceleri başka bir işlevde kareye yakın bir plana sahipken daha sonraları haç kolları eklenerek haç planlı martyriuma dönüşmüştür (Crowfoot 1941: 89; Lassus 1947: 126-128).

Binbir Kilisede bulunan 12 nolu yapı, kare ya da kareye yakın merkezi bir mekân ve bu mekânın dik eksenlerindeki haç kollarından oluşan mimariye sahiptir (Eyice 1971: 28; Pekak 2008: 86).

4. yüzyıla tarihlenen Antakya'da yapılan Aziz Babylas'ın martyriumu haç planlıdır. Merkezdeki kare planlı bölümün kuzeybatısındaki Aziz Babylas ve 379-381 yılları arasında martyriumu yaptıran Piskopos Meletios'un mezarları bulunmaktadır (Downey 1935: 45-48; Lassus 1947: 123-126; Krautheimer 1986: 52).

\section{Martyrium Yapılarının Kiliselerle Olan İlişkisi}

4. yüzyılla birlikte öncülüğünü İmparator mozolelerinden alan martyrium yapıları, Hz. İsa'nın yaşamını sürdüğü ve Hristiyanlık doktrinini yaydığı bölge olan Kutsal Topraklar ile tanınmıştır. Bu topraklarda bu yapılar martyr mezarlarının üzerine yapıldığı gibi içerisinde rölik içermemesine rağmen İsa'nın mucizelerinin gerçekleştiği yerlerde birer rölik kabul edilmiş ve bu alanlara da martyrium yapıları yapılmıştır. Bu duruma örnek olarak $\mathrm{Hz}$ İbrahim' in tanrı ile konuştuğu ağacın altındaki alan 330 yıllarında İmparator Constantinus bazilikal planlı, tek nefli bir yapı gösterilebilir. S. Hill (1996: 32), bu yapının kutsal bir mekânda kutsal bir olayın anılması için yapılmış bir martyrium yapısı olduğunu ifade eder.

İlk başlarda bu martyriumlar bazilikal plan ile tümleşik olarak yapılmışlardır. Normal litürjinin uygulandığı bu bazilikal planlı kiliselerde martyrium, yap1 grubunun bir parçası olmaktan çok odağ1 olmuştur. Hristiyanlık öğretilerini yayarken yaşamlarından vazgeçen martyrlerin mezarları gibi imparatorluk ailesi üyelerinin mezarlarının 
yanlarına yapılan kiliselerde bulunmaktadır. Zamanla imparatorluk mozoleleri de yanlarına dini yapı eklenmesiyle birer martyrium yapıs1 gibi rağbet görmüşlerdir. $\mathrm{Bu}$ duruma en iyi örnek, İmparator Constantinus'un kızına ait olan S. Agnese'deki S. Costanza mozolesidir. 350 yıllarında bağımsız bir yapı olarak tasarlanan mozolenin yanına daha sonradan kilise inşaa edilmiştir ${ }^{18}$.

İmparator Constantinus döneminde yapımına başlanan Yeniden Diriliş Kilisesi'nin batısına konumlanan martyriumun, kiliseden önce

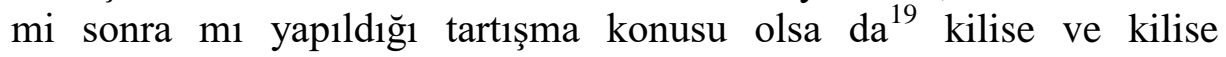
mimarisinden bağımsız olarak yapılmış merkezi planlı bir martyriumun tümleşik olarak kullanıldığı örnekler arasındadır ${ }^{20}$.

325 y1lında $\mathrm{Hz}$ İsa'nın mezarının üstüne çevre koridorlu, yuvarlık planlı "Anastasis Rotondu" veya "Mezar Rotondu" yapılmıştır (Resim 14). Daha sonra yapının doğu kısmında bulunan ön avluya doğru beş nefli bazilika yapılmıştır. Kudüs Kutsal Mezar Kilisesi mezarın üzerindeki merkezi planlı martyriumla bazilikal planlı büyük bir cemaat kilisesinin birleşmesinden oluşmuştur. Hacılar mezarı ziyaret edebilecek ve daha sonra cemaatin toplanıp törenlerini yapabilecekleri bir alan oluşturulmuştur ${ }^{21}$. Hz İsa'nın doğduğu yeri barındıran ve Beytüllahim'deki Doğuş Kilisesinin apsisinin yerine aldığı yap1, ilk önce İsa'nın doğduğu alanın üzerine yapılmış çokgen planlı bir

\footnotetext{
${ }^{18}$ S. Constanza için bk. Krautheimer 1986: 65.

19325 yılındaki İznik konsilinde, Kudüs piskoposu Macarius Aphrodite tapınağının altındaki İsa'nın mezarını çıkartıp, bir mezar yapısının içine konulmasını talep etmiştir. Bu talep karşılığında İmparator Constantius mezarı çıkartmıştır. Ancak 333 yılında bazilikal planlı kilisenin inşaatı tamamlanmıştır. Kilisenin inşaatı boyunca mezar bir avlu içinde barındırılmıştır (Couasnon 1974: 12-14).

${ }^{20}$ Yeniden Diriliş Kilise için bk. Koch 2015: 51, res: 9 lev. 1, 2.

${ }^{21}$ Beytüllahim Doğuş Kilisesinde de yine durum aynıdır. İsa'nın doğduğu mağara üzerine, içinde mezar olmaksızın sekizgen bir martyrium yapılmış, batısına da bir bazilika eklenmiştir (Koch 2015: 34).
}

Uludağ Üniversitesi Fen-Edebiyat Fakültesi Sosyal Bilimler Dergisi Uludağ University Faculty of Arts and Sciences Journal of Social Sciences

Cilt: 21 Sayl: 39 / Volume: 21 Issue: 39 
martyriumken Justinianus Dönemi'nde buraya bazilikal planlı kilise eklenmiştir. Böylece çokgen formda olan martyrium Doğuş Kilisesinin apsisi konumuna geçmiştir (Resim 15). Burayı ziyaret eden hacılar için atriumda veya neflerde olan basamaklar apsisteki martyriuma bakmaları için tasarlanmıştır (Krautheimer 1986: 60). Böylece martyriumla birleşen kilise haç kilisesi haline dönüşmüştür.

\section{Sonuç}

Geç Antik Çă̆'da Hristiyanlıkla beraber meydana çıkan martyriumlar, anıt mezar yapı anlayışının tarihsel süreç içerisinde gelişimlerinin incelendiğinde kökeninin, klasik dünyadaki pagan uygulamalardan olan heroonlardan yapılış amaçlarına göre çokta farklı olmadığı görülmüştür. Kahramanlık kültünün, Hristiyanlığın erken dönemlerinde oluşan martry kültüne dönüşüp, tıpkı heroonlar gibi anıtsal mezar mimarisi olarak karşımıza martyriumlar olarak çıktığını görebiliriz. Martyriumlara mimari olarak bir öncü niteliğinde olmayan heroonlar, yapılış amacı açısından martyriumlara ilham verdiği şüphesizdir.

Tek tanrılı din olan Hristiyanlığın erken dönemlerinde din şehidi olan martyrler için yapılan martyriumların yapılış amaçları açısından incelendiğinde ilk ortaya çıktıklarında heroon kültüyle beraber pagan anıt mezarlarından etkilenmişlerdir. Mimari plan özelliklerinde ise Geç Roma İmparatorluk saraylarındaki kabul salonları ya da resmi ziyafet salonları olan tricliniumlardan etkilendikleri gibi şüphesiz imparatorluk mozoleleri de diğer etki alanları olmalıydı.

Geç Antik Çağ Erken Hristiyanlık Döneminde Anadolu'da ise hemen hemen bütün kentler kendi yerel martyr kültünü yaratmış ve bu kültü barındıran birer martyrium yapısına sahip olmuşlardır. Martyr kültünün mimari yansıması olan martyriumlar genellikle özerk yapılar olup kilise yanlarında yer almaktaydılar. Constantinople'de bulunan Aziz Karpos ve Papylos Martyriumu, Balabanağa Mescidi’nin ilk 
evresindeki martyrium yapısı, Hebdomon Martyriumu, Kocaeli Gültepe Park'ta bulunan martyrium yapısı, Hierapolis'te bulunan martyrium, Binbir Kilise'de bulunan 8 ve 12 nolu yapılar, Seleukia Pieria'daki martyrium, Hatay'da bulunan martyrium yapısı, Antakya'daki Aziz Babylas Martyrium'u, Constantia'daki Aziz Thomas Martyrium'u gibi martyriumlar kilise mimarisinden ayrı, özerk anıtsal martyriumlardır (Resim 16).

Constantinople'de bulunan Aziz Maria Chalkoprateia Kilisesi, Kissebükü'ndeki 2 numaralı bazilika, Binbir Kilise 8 Nolu ve 12 nolu yap1, Chalcedon'da bulunan Azize Eupheima Kilisesi, Kudüs Kutsal Mezar Kilisesi ve Beytüllehim Doğuş Kilisesi yanlarında var olan martyriumlardan sonra yapılmış olmalıdır. Çünkü zaten Hristiyanlığın ilk üç yüz yıllında şehit edilen kişilerin mezarları olan martyriumlar, tarihsel süreç içiresinde yanındaki kiliseden önce yapılmış olması daha mantıklı bir çıkarımdır.

Erken Hristiyanlı dönemi kült yapılarından olan martyriumların, diğer yapılardan işlevine göre ayrılmış, kendilerine has bir mimariyi ortaya koyduklarını söyleyebiliriz. Martyrium mimarisi; tonozlu, merkezi planlı, dairesel, çokgen ve haç planlı, oldukça basit üsluptadır. Anadolu'da bulunan Geç Antik Çă̆ Erken Hristiyanlık martyriumlarıda kutsal topraklarda bulunan martyrium yapılarıyla aynı mimari plan özellikleri göstermektedir. Başlangıçta dini yapılardan bağımsız gelişen martyriumların daha sonraları yakın konumlarına kiliseler eklenmesiyle varlıklarına devam etmişlerdir.

\section{Resimlerin Listesi}

Resim 1: Limyra Heroon (Novakova 2016: fig.1)

Resim 2: Sagalassos Heroon

(https://www.flickr.com/photos/johanbakker/15795105280/in/photostre $\underline{\mathrm{am} /)}$ (Erişim Tarihi: 19.01.2020) 
Resim 3: S. Costanza Mozolesi

(https://www.rijksmuseum.nl/en/collection/RP-P-OB-39.442) (Erişim Tarihi: 19.01.2020)

Resim 4: Aziz Karpos ve Papylos martyriumu planı (Beygo 2006: şek. 2.11)

Resim 5: Balabanağa Mescidi planı (Mansel 1930: res.: 4

Resim 6: Hebdomon Hipojesi (Mansel 1930: res.: 24)

Resim 7: Aziz Philippus Martyriumu

(http://antiqueanatolian.blogspot.com/2008/04/) (Erişim Tarihi: 19.01.2020)

Resim 8: Constantia Martyrium Yapıs1 (Keser Kayaalp 2013: fig.: 10)

Resim 9: Leontopolis Sekizgen Planlı Yapı (Mimiroğlu 2015: şekil: 71)

Resim 10: Seleucia Pieria Martyrium Yapısı (Krautheimer 1986)

Resim 11: Hatay-Armutlu Martyrium Yapısı (Aydın Çilingir 2017: çiz. 3)

Resim 12: Kocaeli Gültepe Parkı Martyrium Yapısı (Demir 1993: plan: 3)

Resim 13: Sırbistan Niş Çariçingrad Martyriumu (Eyice 1952: çiz. 14)

Resim 14: Kudüs Kutsal Mezar Kilisesi (Beygo 2006, şek.: 3.8)

Resim 15: Beytüllahim Doğuş Kilisesi (Beygo 2006: şek.: 3.7)

Resim 16: Anadolu'da Bulunan Martyrium Yapılarının Mimari Tipleri (Yazar 27.12.2019) 


\section{Kaynaklar}

Akçay, Tuna (2008). Olba Mezarları. Yüksek Lisans Tezi. Mersin: Mersin Üniversitesi.

Akyürek, Engin (1998). "Bizanslilar, Azizleri ve Khalkedon'lu Azize Euphemia”. Sanat Dünyamı, S. 69-70, s. 175-190.

Arslan, Anıl (2013). "Mylasa'dan Halikarnassos'a Hekatomnidler". Kocaeli: Uluslararası Sosyal Araştırmalar Dergisi, S. 6, s. 47-57.

Aydın, Mehmet (2017). "Hatay-Defne Kent Meydanı Kurtarma Kazısı". Müze Çalışmaları ve Kurtarma Kazıları Sempozyumu, S. 26, s. 189202.

Bayülgen, Batu (2012). Hagioi Segios ve Bakkhos Kilisesi Yeni Mimari Bulgular ve Tipolojisi, Doktora Tezi. İstanbul: İstanbul Teknik Üniversitesi.

Beygo, Ayça (2006). İstanbul Samatya'da Karpos Papylos Martirion'u. Yüksek Lisans Tezi. İstanbul: İstanbul Teknik Üniversitesi.

Borchhardt, Jürgen (1999). Limyra Zemuri Taşlart. İstanbul: Arkeoloji ve Sanat Yayınları.

Brandt, Olof (2006). "The Lateran Baptistery and the Diffusion of Octagonal Baptisteries from Rome to Constantinople". Vindobonae: Acta Congressus Internationalis XIV Archaeologiae Christianae, S. 19, s. 221-227.

Brenk, Beat (1980). Propylaen Kunst Geschichte, Spaetantike und Früheschristetum. Mainz-Berlin-Wien: Propylaea.

Brown, Peter (1982). The Cult of the Saints. Newyork: The University of Chicago Press.

(1982). "In Gibbon's Shade". London: Society and the Holy in Late Antiquity, S. 35, s. 49-62. 
Butler, Howard Crosby (1913). "Fourth Preliminary Report on the American Excavations at Sardes in Asia Minor". American Journal of Archaeology, C. 17, S. 4, s. 471-478.

Couasnon, Charles (1974). The Church of the Holy Sepulchre in Jerusalem. London: Oxford University Press.

Colvin, Howard (1991). Architecture and the After-Life. London: The Yale University Press.

Crowfoot, John Winter (1941). Early Churches in Palastine. London: British Academy.

Davies, John Gordon (1980). "Baptisterium". Berlin: Theologischer Realenzyklopädie, C. IV, s. 200.

D’Andria, Francesco (2010). Hierapolis (Pamukkale) Arkeoloji Rehberi. Çev: Nezih Fırat, İstanbul: Ege Yayınları.

De Chapeaurouge, Donat (1991). Einführung in die Geschichte der christlichen Symbole. Darmstad: Wissenschaftliche Buchgesellschaft.

Deichmann, Friedrich Wilhelm (1954). "Cella Trichora". Reallexikon für Antike und Christentum, S. V.II, s. 944-954.

Demir, Zeynep (1993). "Kınal1-Sakarya Otoyolu 88. Km İzmit Kesimi Gülhane Park Alanı Nekropolü 1992 Y1lı Kurtarma Kazısı”. Müze Kurtarma Kazıları Sonuçları, S. 4, 357-377.

Downey, Geraldine (1959). "The Tombs of the Byzantine Emperors in the Church of the HolyApostles in Constantinopole". Journal of Hellenic Studies, S. 79, s. 27-51.

Dölger, Franz Joseph (1934). "Zur Symbolik des christlichen Taufhauses”. Antike und Christentum, S. 4, s. 153-187.

Erdem, Burak (2015). Doğu Dağlık Kilikia Mezarları. Yüksek Lisans Tezi. Ankara: Gazi Üniversitesi. 
Eyice, Semavi (1952). “Amasra Büyükada'sında Bir Bizans Kilisesi”. Belleten, C. 15, S. 60, s. 470-496.

(1971). Karadağ (Binbirkilise) ve Karaman. Recherches archéologiques à Karadağ (Binbirkilise) et dans la région de Karaman. Ankara: Türk Tarih Kurumu Yayınları.

(1988). "Bizans Mimarisi Mimarbaşı Koca Sinan

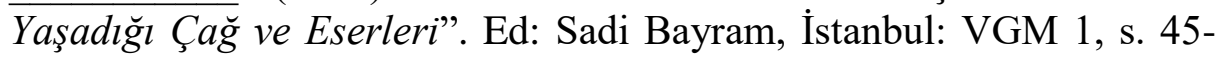
51.

Grabar, Andre (1953). Byzantine Painting. Geneva: Rizolli International Publications.

Gurlitt, Cornelius (1907). Die Baununst Konstantinopels. Berlin: E Wasmuth.

Harrison, Martin (1963). "Churches and Chapels of Central Lycia". Anatolia Studies, S. 13, s. 47-151.

Heiser, Lothar (1987). Die Taufe in der Orthodoxen Kirche. Trier: Paulinus-Verlag.

Henning, Agnes (2013). The Tower Tombs of Palmyra: Chronology, Architecture and Decoration. Studia Palmyrenskie 12, Fifty Years of Polish Excavations in Palmyra 1959-2009, International Conference, 68 December 2010, Warsaw: Polish Centre of Mediterranean Archaeology, University of Warsaw (PCMA UW), Wydawnictwa Uniwersytetu Warszawskiego (WUW), s. 159-175.

Hill, Stephen (1996). The Early Byzantine Churches of Cilicia and Isauria. Aldershot, UK: Variorum.

https://rome.us/ancient-rome/the-appian-way.html (Erişim Tarihi: 07.01.2020) 
https://www.flickr.com/photos/johanbakker/15795105280/in/photostrea $\underline{\mathrm{m} / \text { (Erişim Tarihi: } 19.01 .2020)}$

http://antiqueanatolian.blogspot.com/2008/04/ (Erişim Tarihi: 19.01.2020)

Kara, Onur (2015). “Antalya Müzesi Müdürlüğü Başkanlığı'nda Perge Antik Kenti 2013 Y1lı Kazıları”. Müze Çalışmaları ve Kurtarma Kazıları Sempozyumu, S. 23, s. 427-449.

Kasapoğlu, Hasan (2007). "Parion Nekropolü Mezar Tipleri”. Atatürk Üniversitesi 50. Kuruluş Yıl Dönümü Arkeoloji Bölümü Armağanı, Ed: Birol Can, Mehmet Işıklı, Erzurum: Atatürk Üniversitesi Yayınları, s. 481-521.

Kazhdan, Alexander ve Nancy Şevçenko (1991). "Symeon Metaphrastes". The Oxford Dictionary of Byzantium, S. 3, Newyork: Oxford University Press.

Keser Kayaalp, Elif (2013). "The Church of Virgin at Amida and the Martirium at Constantia: Two Monumental Centralised Churches in Late Antique Northern Mesopotamia”. OLBA, S. XXI, s. 388-436.

Kızıl, Abuzer (1999). Karya Bölgesi Roma Dönemi Anıt Mezarlarl. Doktora Tezi, Konya: Selçuk Üniversitesi.

Koch, Guntram (2001). Roma Dönemi Imparatorluk Lahitleri. Çev: Zühre İlkgelen, İstanbul: Arkeoloji ve Sanat Yayınları.

(2015). Türkiye'deki Geç Antik Dönem Merkezleri ile Birlikte Erken Hıristiyan Sanatı. Çev: Ayşe Aydın, İstanbul: Arkeoloji ve Sanat Yayınları.

Krautheimer, Richard (1986). Early Christian and Byzantine Architecture. London: The Yale University Press. 
Lavin, Irving (1962). "The House of the Lord: Aspects of the Role of Palace Triclinia in the Architecture of Late Antiquity and the Early Middle Ages". The Art Bulletin, S. 44, s. 1-27.

Lassus, Jean (1947). Sanctuaries chétiens de Syrie. Paris: Beyrouth.

Limberis, Vasiliki (2011). Architects of Piety: The Cappadocian Fathers and the Cult of Martirs. Melbourne: Oxford University Press.

MacDonald, William (1986). The Architecture of the Roman Empire, Volume II: An Urban Appraisal. London: Yale University Press.

Machatschek, Alois (1974). "Die Grabtempel von Dösene im Rauhen Kilikien". Mansel'e Armağan, Ankara: Türk Tarih Kurumu Yayınları, s. 251-261.

Macridy, Theodore ve Jean Elbersolt (1922). "Monuments funéraires de Constantinople". Bulletin Decorrespondance Hellénique, S. 46, s. 356393.

Mango, Cyrill (1986). The Art of the Byzantine Empire 312-1453, Sources and Documents. Toronto: University of Toronto Press.

Mansel, Arif Müfid (1936). "Balabanağa Mescidi Hafriyatı". Türk Tarih, Arkeologya ve Etnografya Dergisi, S. III, s. 49-75.

(1978). Ege ve Yunan Tarihi. Ankara: Türk Tarih

Kurumu Yayınları.

Mazzotti, Marco (1961). "Il Battistero della Cattedrale di Ravenna. Problemi Architettonici e Vicende del monument". Corsi di Cultura sull'arte Ravennate e Bizantina, S. 12-24, s. 255-278.

Mercangöz, Zeynep (1990). “Bafa Gölü, Kirselik’teki Manastır Kilisesi". Arkeoloji ve Sanat Tarihi Dergisi, S. 5, s. 117-138.

Milburn, Robert (1998). Early Christian Art and Architecture. Los Angeles: University of California Press. 
Mimiroğlu, İ. Mete (2015). Konya'nın Bizans Dönemi Mimarisi. Doktora Tezi. Konya: Selçuk Üniversitesi.

Moss, Candida (2013). The Myth of Persecution: How Early-Christians Invented a Story of Martirdo. San Francisco: HarperOne.

Nováková, Lucia (2016). "Burial Places outside the Sanctuary: Centre of Religious Life". ANADOS, S. 12, s. 193-204.

Olcay Uçkan, B. Yelda (2007). "Frigya (Phrygia) Bölgesi Kaya Kiliseleri”. 24. 2. Araştırma Sonuçları Toplantısı, s. 101-112.

(2008). "Olympos Kazıs1 2007 Excavations at Olympos in 2007". Anadolu Akdenizi Arkeoloji Haberleri, S. 8, s. 5257.

Özbek, Çiğdem (2007). "Anadolu'nun Hellenistik ve Roma Dönemi Anıt Mezar Geleneğine Bir Bakış”. Patronvs Coşkun Özgünel'e 65. Yaş Armağanı, s. 265-271.

Özüdoğru, Şükrü (2008). Arkaik Dönem Lykia Plastik Eserleri Işı̆̆ında Ikonografik Yerel ve Yabancı Unsurlar. Doktora Tezi, Antalya: Akdeniz Üniversitesi.

Parman, Ebru (2001). "Antalya-Olympos ve Çevresi (Geç AntikOrtaçağ) Yüzey Araştırmaları 2000 Yılı Çalışma Raporu”. Araştırma Sonuçları Toplantısı, S. 19, s. 137-144.

Ramsey, William ve Gertrude L. Bell (1909). The Thousand and One Churches. London: Hodder Publisher.

Roth, Leland (2018). Mimarlığın Öyküsü Öğeleri, Tarihi ve Anlamı. Çev. Ergün Akça, İstanbul: Kabalcı Yayınevi.

Ruggieri Vincenzo (2003). Il golfo di Keramos: dal Terdo- Antico al Medioevo Bizantino. Soveria Mannelli: Rubbettino Publisher. 
Schneider, Alfons Maria (1936). Byzanz. Vorarbeiten zur topographie und Archaeologie der Stadt. Berlin: Verlag Adolf.

Söğüt, Bilal (2006). Dağllk Kilikya (Kilikia) Bölgesindeki Çokgen Taş Duvarlı Mezarlar. İstanbul: Ege Yayınları.

Stollmayer, John (1999). "Spatantake Trikonkhoskirchen Ein. Baukonzept". Jahrbuch für Antike und Christentum Jahrgang, S. 42, s. 116-157.

Sunay, Serkan (2012). "Erken Hıristiyan ve Bizans Sanatında Hale". Ekev Akademi Dergisi, S. 50, s. 197-213.

Toynbee, Jocelyn Mary Catherine (1971). Death and Burial in the Roman World. Baltimore: JHU Press.

Van Millingen, Alexander (1912). Byzantine Churches in Constantinople; Their History and Architecture. assisted by Ramsay Traquair, W. S. George and A. E. Henderson, London: MacMillan and Co.

Vickers, Michael (1973). "Observations on the Octagon at Thessaloniki”. Journal of Roman Studies, S. 63, s. 111-120.

Ward-Perkins, John Bryan (1994). Studies in Roman and Early Christian Architecture. London: The Pindar Press.

Y1lmaz, Nalan (2007). "Necropoleis and Funerary Monuments in Pisidia during the Roman Period". Adalya, S. 10, s. 155-204. 


\section{Resimler}

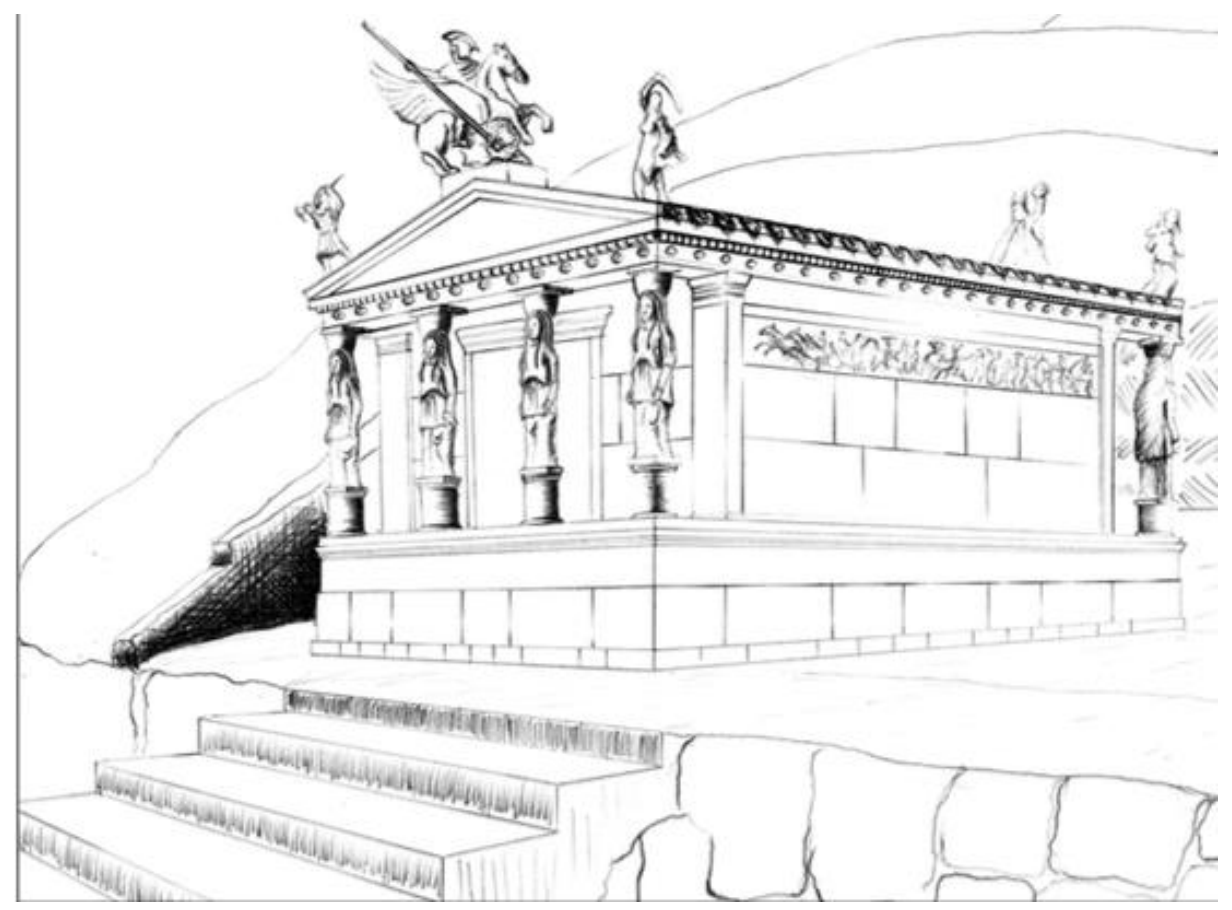

Resim 1: Limyra Perikle'nin Heroonu

Uludağ Üniversitesi Fen-Edebiyat Fakültesi Sosyal Bilimler Dergisi Uludağ University Faculty of Arts and Sciences Journal of Social Sciences Cilt: 21 Sayl: 39 / Volume: 21 Issue: 39 


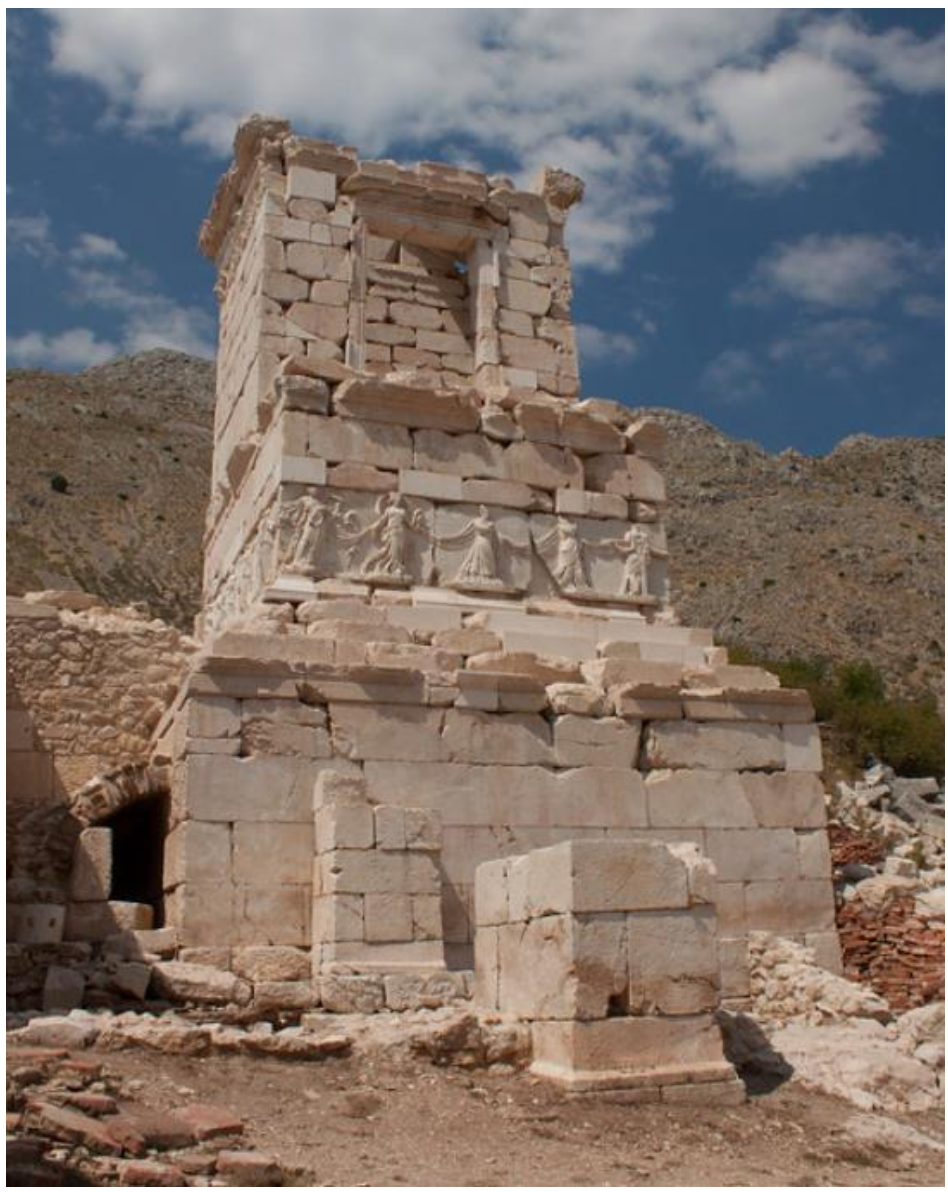

Resim 2: Sagalassos Heroon

Uludağ Üniversitesi Fen-Edebiyat Fakültesi Sosyal Bilimler Dergisi Uludağ University Faculty of Arts and Sciences Journal of Social Sciences Cilt: 21 Sayl: 39 / Volume: 21 Issue: 39 


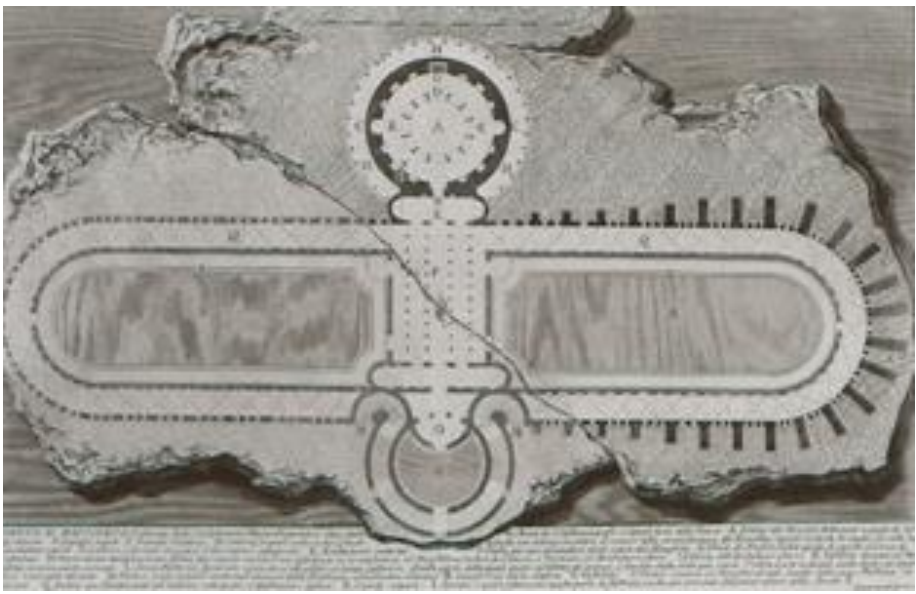

Resim 3: S. Costanza Mozolesi

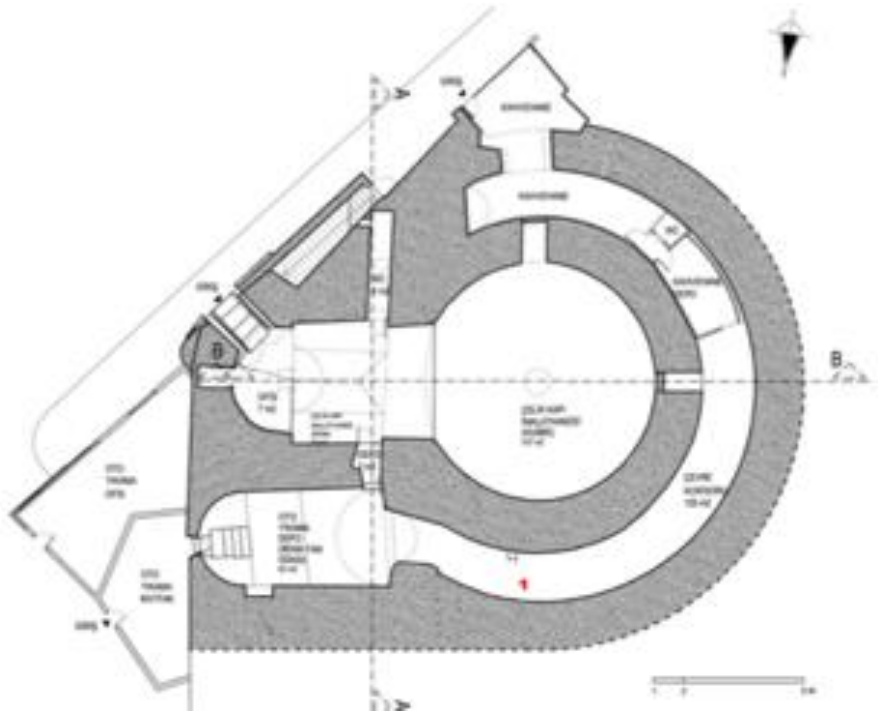

Resim 4: Aziz Karpos ve Papylos martyriumu planı

Uludağ Üniversitesi Fen-Edebiyat Fakültesi Sosyal Bilimler Dergisi Uludağ University Faculty of Arts and Sciences Journal of Social Sciences Cilt: 21 Sayl: 39 / Volume: 21 Issue: 39 


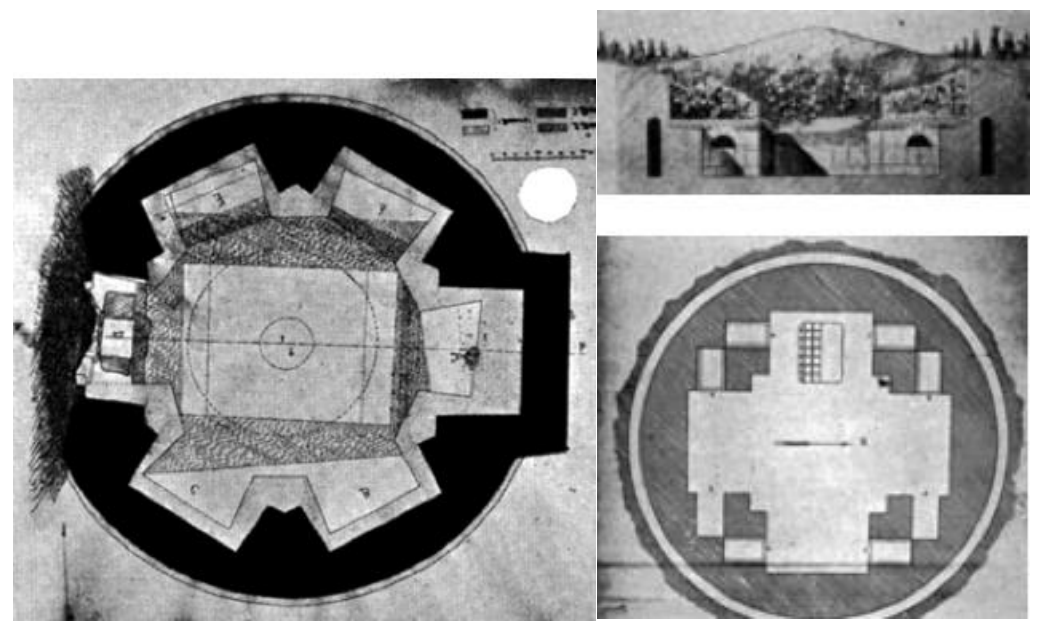

Resim 5: Balabanağa Mescidi planı Resim 6: Hebdomon Hipojesi
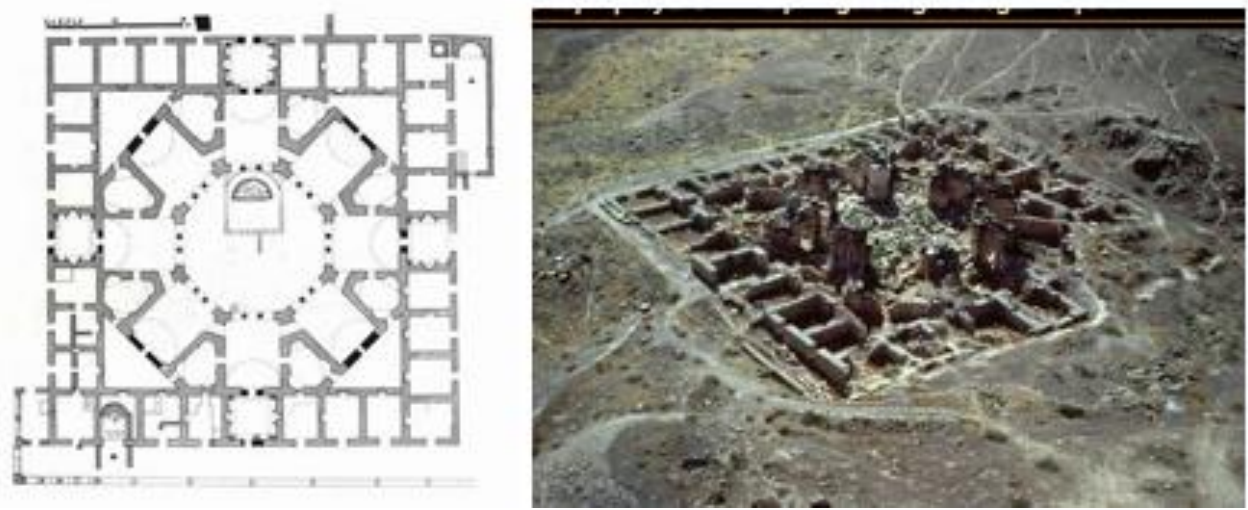

Resim 7: Aziz Philippus Martyriumu

Uludağ Üniversitesi Fen-Edebiyat Fakültesi Sosyal Bilimler Dergisi Uludağ University Faculty of Arts and Sciences Journal of Social Sciences Cilt: 21 Sayl: 39 / Volume: 21 Issue: 39 


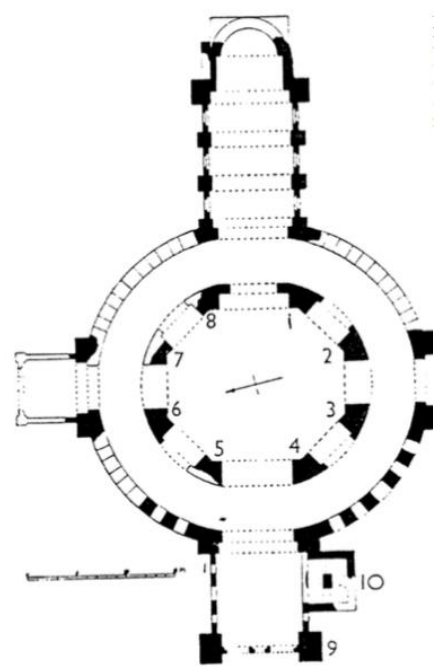

Resim 8: Constantia Martyrium Yapıs1 Resim 9: Leontopolis Sekizgen Planlı Yap1

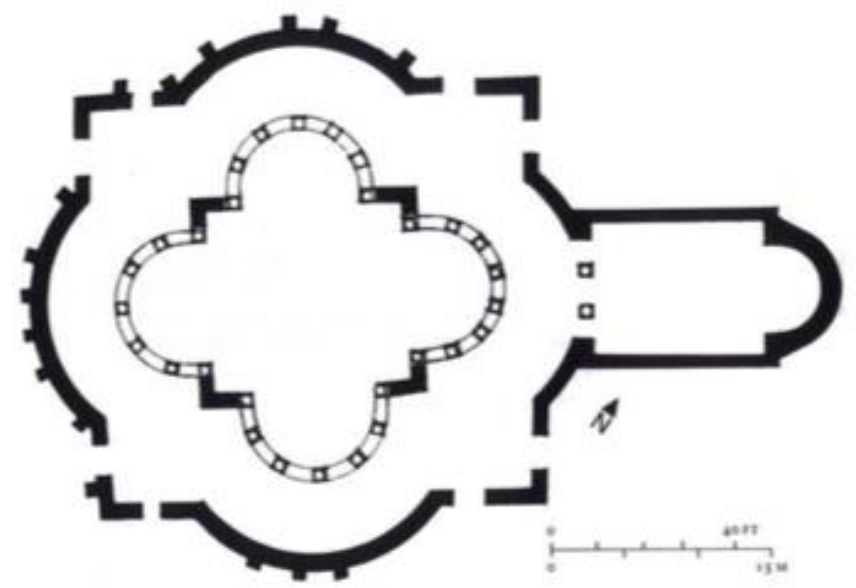

Resim 10: Seleucia Pieria Martyrium Yapıs1

Uludağ Üniversitesi Fen-Edebiyat Fakültesi Sosyal Bilimler Dergisi Uludağ University Faculty of Arts and Sciences Journal of Social Sciences Cilt: 21 Sayı: 39 / Volume: 21 Issue: 39 

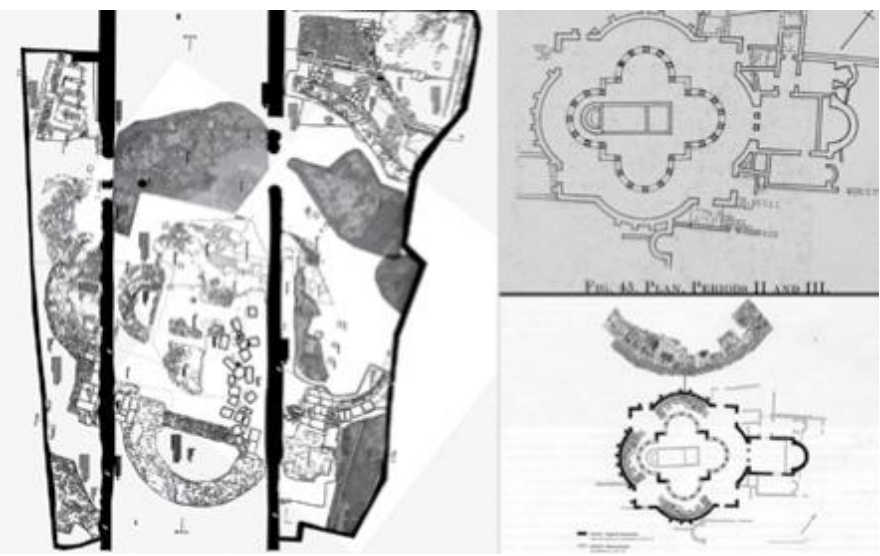

Resim 11: Hatay-Armutlu Martyrium Yapıs1

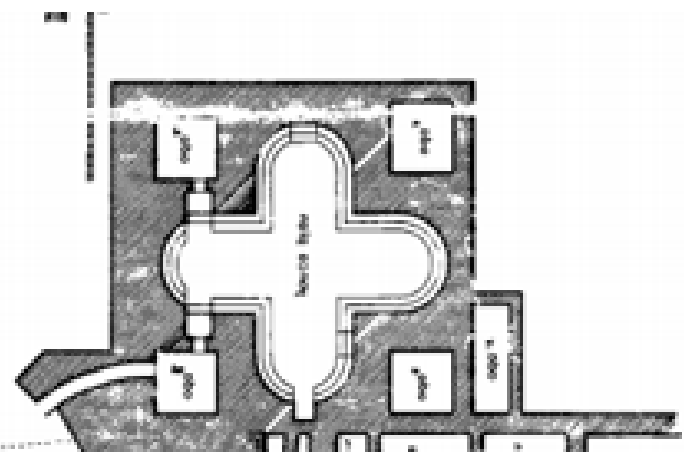

Resim 12: Kocaeli Gültepe Park1 Martyrium Yapısı

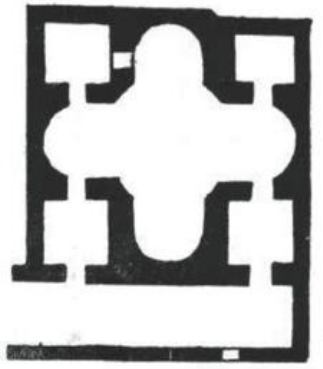

Resim 13: Surbistan Niş

Çariçingrad Martyriumu

Uludağ Üniversitesi Fen-Edebiyat Fakültesi Sosyal Bilimler Dergisi Uludağ University Faculty of Arts and Sciences Journal of Social Sciences Cilt: 21 Sayl: 39 / Volume: 21 Issue: 39 


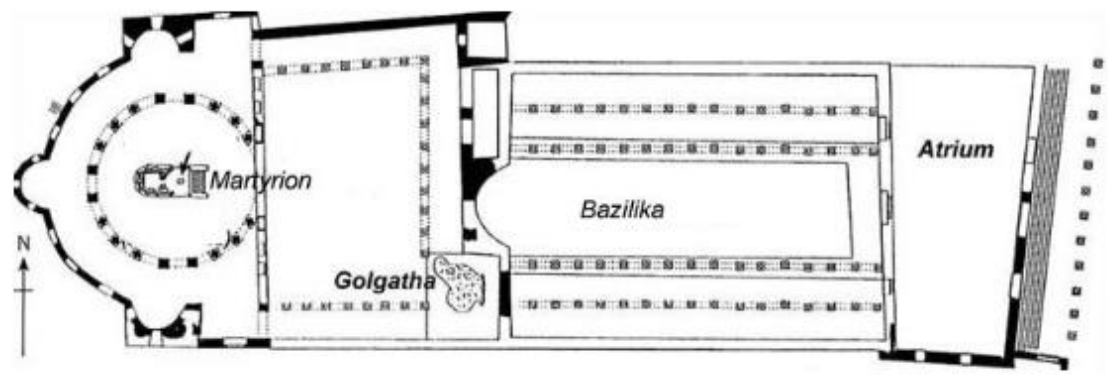

Resim 14: Kudüs Kutsal Mezar Kilisesi

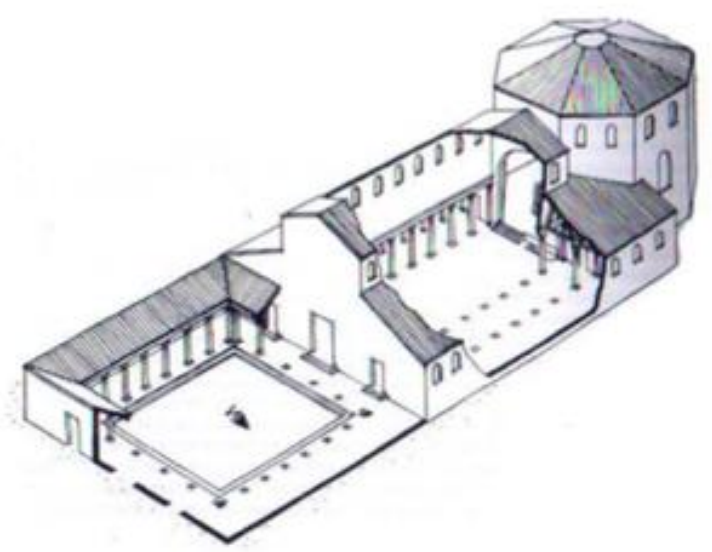

Resim 15: Beytüllahim Doğuş Kilisesi

Uludağ Üniversitesi Fen-Edebiyat Fakültesi Sosyal Bilimler Dergisi Uludağ University Faculty of Arts and Sciences Journal of Social Sciences Cilt: 21 Sayl: 39 / Volume: 21 Issue: 39 


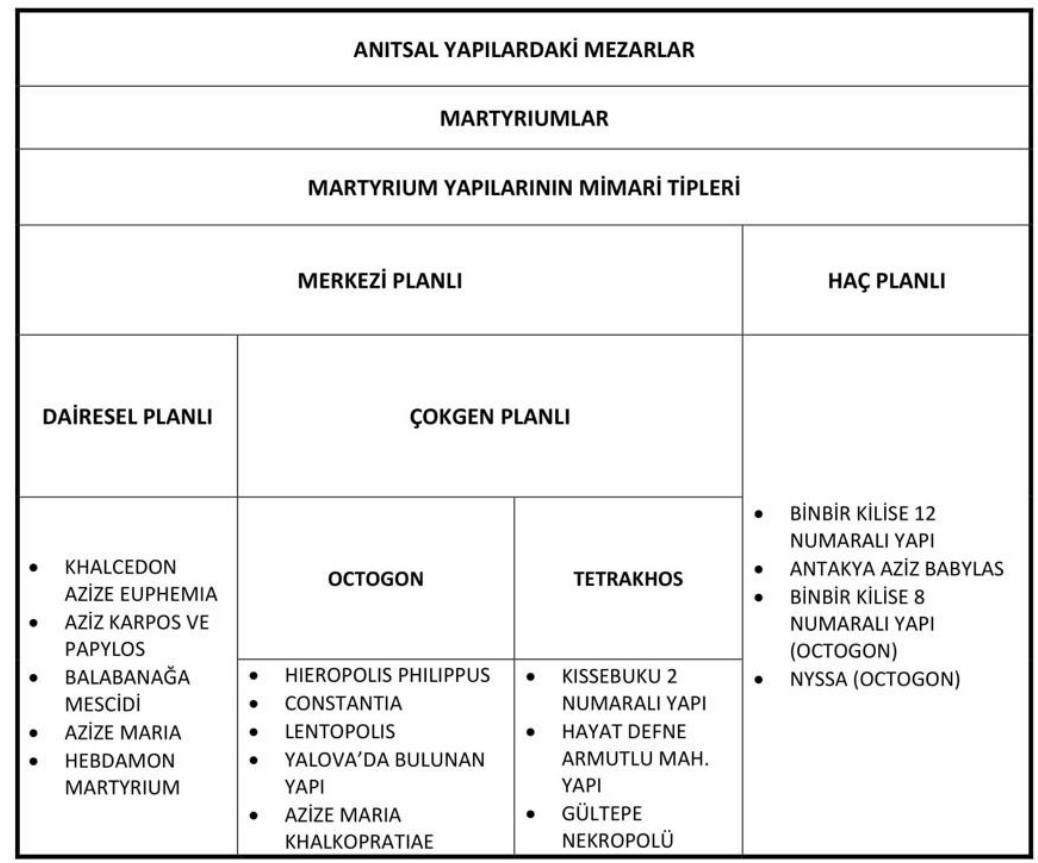

Resim 16: Anadolu'da Bulunan Martyrium Yapılarının Mimari Tipleri 


\section{EXTENDED ABSTRACT}

The monumental tombs, whose aim is to immortalize the position of the deceased while living, and pass it on to the next generations, were made for rulers, heroes and nobles, not for ordinary citizens. Since the times when the concept of urbanism was fully established, it has become the symbol of wealth and prosperity as an architectural reflection of political and social propaganda in monumental tombs, such as big temples, theaters, city squares, monuments of victory. These monumental tombs, made for noble rulers and heroes, have become symbols of honoring and immortalization. These monumental graves that we encounter in almost every region of Anatolia should be accepted as heroons. Starting from the 7th century BC, heroons have been dedicated only to city founders, administrators honored by the townspeople, successful athletes, donors, donors, and heroes who have succeeded in military terms. This situation continued in the classical period, and they also took place at a certain point outside the city. With the Hellenistic Period, the traditional approach has changed, these tombs have begun to approach the city, and they have been built completely in the city since the 1st century $B C$, and have been built among the people depending on the material level of the deceased. Thus, during the Roman Imperial Period, the term heroism lost its original meaning and a monumental tomb type was made for everyone with high income.

With the acceptance of Christianity in the Roman Empire, the architectural style changed in parallel with the returns of new faith. The monumental tomb / heroon concept, as in the Classical Period, appears as martyrians where not only the rich or noble, but also martyrs of religion, that is, martyrs, with the Roman Imperial Period. The heroic cult in Pagan and the heroons formed with it formed the origin of the Christian martyr cult and martyrium in the early $3 r d$ century. In this study, in which the martyrians, which are the monumental tombs of the Late Antiquity and Early Christianity, are examined, firstly, how the changing world view of human beings reflected on the monumental grave types is emphasized. In the study, later, the architectural development of martyrium structures, which is the reflection of the martyr cult in Christianity, which is the monotheistic belief in Late Antiquity, was examined. It can be said that it originated from the Roman Imperial reception halls, imperial cult mausoleums. As a result of the literature study, it was observed that martyrium structures were built in two different plans as central and cross according to the plan features. It is understood that the central plan, which is widely used in christian architecture, was applied in circular and polygonal forms in martyrium structures. 
We can say that the martyrium, which is one of the cult buildings of the early Christian era, is differentiated from other structures by its function and reveals its own architecture. Martyrium architecture; It has a vaulted, central plan, circular, polygon and cross plan and it is in a very simple style. The Late Antiquity Early Christian martyria in Anatolia show the same architectural plan features as the martyrium structures found in the holy land. Originally developed independently of religious structures, the martyria continued their existence later with the addition of churches to their nearby locations. 